\title{
Herbicide free agriculture? A bio- economic modelling application to Swiss wheat production
}

\section{Journal Article}

Author(s):

Böcker, Thomas; Möhring, Niklas (D); Finger, Robert (D)

Publication date:

2019-07

Permanent link:

https://doi.org/10.3929/ethz-b-000336277

Rights / license:

Creative Commons Attribution-NonCommercial-NoDerivatives 4.0 International

Originally published in:

Agricultural Systems 173, https://doi.org/10.1016/j.agsy.2019.03.001 


\section{Postprint}

This is the accepted version of a paper published in Agricultural Systems. This paper has been peer-reviewed but does not include the final publisher proof-corrections or journal pagination.

\section{Citation for the original published paper:}

Böcker, T., Möhring, N., Finger, R. (2019). Herbicide free agriculture? A bio-economic modelling application to Swiss wheat production. Agricultural Systems 173, 378-392

https://doi.org/10.1016/j.agsy.2019.03.001

Access to the published version may require subscription.

N.B. When citing this work, cite the original published paper. 


\title{
Herbicide free agriculture? A bio-economic modelling
}

\section{application to Swiss wheat production}

\author{
Authors: Thomas Böcker ${ }^{\mathrm{a}}$, Niklas Möhring ${ }^{\mathrm{a}}$ and Robert Finger ${ }^{\mathrm{a}, *}$ \\ a Agricultural Economics and Policy Group, ETH Zürich, Switzerland \\ * Corresponding author. Agricultural Economics and Policy Group, ETH Zürich, \\ Sonneggstrasse 33, 8092 Zürich, Switzerland. Tel.: +41(0)4463-25391, Email: \\ rofinger@ethz.ch
}

\section{Acknowledgement}

We would like to thank Agroscope for providing the access to the data of the Swiss Agri-Environmental Data Network, InfoFlora for providing access to the data on weed abundance, IP-Suisse for providing yield data for Extenso wheat production, the Swiss Federal Statistical Office for provision of the land use map. We thank the JOWA (especially Christian Städeli and Christoph Stalder) and IP-Suisse (especially Sandro Rechsteiner and Fritz Rothen), for their comments and support. We also thank Bernhard Streit and Simon Briner for their constructive comments on assumptions and data sources used in this project. The valuable input by Christian Stamm on herbicide loads in Switzerland and the support from Vivienne Oggier, Melissa Uldry and Jasmin Brunner in the data collection process is acknowledged. We thank two anonymous reviewers for constructive comments on an earlier version of this paper. This research was financially supported by the ETH Zurich Research Foundation. 


\title{
Herbicide free agriculture? A bio-economic modelling application to Swiss wheat production
}

\begin{abstract}
Herbicide application in agricultural systems is currently critically discussed because of its possible adverse effects on the environment and human health. Currently, governments and food industry actors search for solutions to reduce herbicide use on farms. Yet, potential consequences of herbicide reductions on a farm-level are not well known. The goal of this article is to develop and apply a bioeconomic modelling approach to simulate how farmers and agricultural systems react to a potential ban of glyphosate and eventually of all herbicides. We apply this approach for Swiss Extenso wheat production, which is a widespread form of wheat production in Switzerland, where pesticide use is currently limited to herbicides and seed treatments. Our modelling approach combines spatially explicit, detailed information on weed pressure, possible yield effects of weeds and efficacy and costs of 140 weed control strategies in a spatially explicit economic decision model. We assess the strategies optimal for farmers in response to i) glyphosate-free and ii) herbicide-free production requirements in terms of economic losses, yield reductions and environmental impacts. We find economic losses in the glyphosate-free production scenario of up to CHF 119/ha and in the herbicide-free scenario of up to CHF 192/ha, with respective yield reductions ranging between $0.8-2.7 \mathrm{dt} / \mathrm{ha}$ (i.e. of up to $6 \%$ ). However, possible economic losses would be outweighed by existing Swiss agri-environmental direct payments for herbicide-free and reduced tillage production systems. We find that restrictions with respect to glyphosate and herbicide use imply trade-offs between the reduction in pesticide risks for the environment and human health versus higher energy consumption. Yet, these trade-offs can be limited if incentive schemes for glyphosate and herbicide reduction are combined with requirements to prevent more intensive tillage.
\end{abstract}

Keywords: Herbicides, winter wheat, extensive production, output damage control, Extenso, Switzerland

\section{Introduction}

The use of pesticides is currently critically discussed and reductions of environmental and human health risks from pesticide use are on top of the agenda of policy makers and food industry. Within these discussions, also bans of certain important pesticides or total bans of all pesticides at large are discussed (e.g. Finger, 2018, see next section for a focus on Switzerland). For instance, three important neonicotinoids have been banned in Europe in 2018. Moreover, the re-licensing process of the broadspectrum herbicide glyphosate aroused intensive policy debates in Europe (cf. Tarazona et al., 2017). 
Glyphosate was re-licensed for five years in Europe in 2017, but the political discussion is still ongoing. Next to the political debate, different stakeholders and private industry push for alternative solutions. For example, in Germany and Austria, some dairies recently adjusted their producer guidelines and excluded glyphosate application from the allowed practices. More general, the reduction of herbicide use plays an important role in current discussions because of a strong increase in applied quantities over the last decades globally (e.g. Benbrook, 2016, Swinton and van Deynze, 2017) and evidence about potential, negative environmental and human health effects (e.g. Brower et al., 2012; Helander et al., 2012, Pimentel et al., 1993, Damalas 2009, Kudsk et al., 2018). In addition, herbicides can be substituted by mechanical or other strategies to some extent (e.g.). In fact, Böcker and Finger (2017) have shown that herbicide use is more price sensitive than the use of other pesticides.

There is so far little evidence about the consequences of a ban of glyphosate or herbicides at large. Potential consequences of such a ban comprise economic losses for farmers and possible yield reductions but also adjustments in production by farmers and related direct and indirect environmental effects. For example, substituting herbicides might increase tillage intensity and thus increase energy use and soil erosion or glyphosate might be substituted with more toxic herbicides instead. Different approaches have been used in recent research to investigate farmers' potential reactions to restricted herbicide use. For instance, Schmitz and Garvert (2012) and Schulte et al. (2017) used expert interviews to explore consequences of a glyphosate ban. Christensen et al. (2011) and Danne et al. (2018) conducted an experimental research design to investigate the importance of glyphosate use and farmers willingness to give up herbicide use. Aiming to combine biophysical and agronomic aspects like weed pressure and efficacy of weed control strategies with an economic decision model, Böcker et al. (2018) developed a bio-economic modelling approach to investigate the effects of a glyphosate ban in maize production in Germany. This approach is more appropriate to investigate effects of possible future policies because in-depth knowledge of all components of the agricultural system can be incorporated. In a recent extension of this model (Böcker et al., 2019), this assessment was complemented in terms of i) pesticide use induced risks for the environment and human health and ii) overall energy use of all weed control strategies. The main finding of these two latter papers is that glyphosate would be mainly substituted by more intense tillage activities, resulting in an overall less toxic but more energy intensive production system.

We develop the approach by Böcker et al. $(2018,2019)$ further and extend the model to also investigate a total ban of herbicides. We apply this model to Extenso wheat production in Switzerland ${ }^{1}$. Extenso wheat is produced under an agri-environmental programme in which farmers receive direct payments if they do not apply fungicides, plant growth regulators, insecticides and chemical-synthetic stimulators

\footnotetext{
${ }^{1}$ Note that a non-peer reviewed short article was published in German and French in a Swiss transfer journal (aimed at practitioners) that summarized the main result of the underlying project (Böcker and Finger, 2018a). Figures 2, 3 and 5 as well as Table 1 thus overlap with content presented there.
} 
of natural resistance. Yet, herbicides are currently still applied. The share of Extenso wheat in Switzerland is about $50 \%$ of total wheat production (see e.g. Finger and El Benni, 2013). Removing also herbicides would create a virtually pesticide-free (yet non-organic) wheat production system - only seed dressing would be still used. Our focus on the prohibition of glyphosate use and the prohibition of all herbicides in Extenso wheat production, reflects currently discussed steps in the Swiss Extenso wheat value chain. A particular emphasis of our analysis is laid on the viability and adoption of reduced tillage practices in combination with glyphosate-free or herbicide-free production. Thus, we explicitly evaluate the above mentioned potential for a substitution of herbicides through mechanical strategies. This is furthermore of importance as agri-environmental programs have already been established in Switzerland to incentivise farmers to adopt such combinations.

We specify and quantify trade-offs arising from stricter (private or public) pesticide policies accounting for various environmental and economic dimensions. In investigating implications of a potential ban of glyphosate and eventually of all herbicides, we especially focus on possible changes in i) weed control measures taken, ii) net profitability, iii) wheat yields as well as iv) potential environmental consequences. The results of this analysis are of importance for policy makers and downstream food industries as possible trade-offs of glyphosate-free and herbicide-free production systems are assessed. Moreover, we identify the role of different policy measures to address these trade-offs. The results are also important for farmers because we assess consequences of a ban at the field- and aggregated level. More generally, our paper develops a highly sophisticated modelling approach that represents a useful basis to further extend the research on the economics of weeds and weed control. The remainder of this article is structured as follows: in the next section, we present a background on Swiss Extenso wheat production, its value chain as well as the relevant agri-environmental programs and pesticide related policy issues. Subsequently, we describe the methodology in order to simulate weed control decisions in winter wheat cultivation and describe the data. Following, we present and discuss the results and draw conclusions..

\section{Background}

Extenso production is an agri-environmental programme in Switzerland for extensive cereal, rapeseed, sunflower and legume production and was initiated in 1992 (see e.g. Finger and El Benni, 2013). For wheat production about $50 \%$ of the Swiss production is produced under this program (BLW, 2016: 241). Participating farms are currently not permitted to apply fungicides, plant growth regulators, insecticides and chemical-synthetic stimulators of natural resistance. Farmers are compensated with an agri-environmental direct payment of CHF (Swiss Francs) 400/ha (Direktzahlungsverordnung Art. 69 
and Annex 7). ${ }^{2}$ This program is supplemental to the standard cross-compliance requirements to receive direct payments (in Switzerland: proof of ecological performance, see e.g. Huber et al., 2017). Moreover, farmers can sell the wheat produced under this program to IP-Suisse, a private trading organisation for food products from integrated agriculture. In this marketing channel, farmers receive an additional price premium on top of the producer price for conventional wheat. In 2018, this premium was between CHF 3.75 and 8.60/ha (on top of about to $52 \mathrm{CHF} / \mathrm{dt}$ [dt $=$ deciton $=100 \mathrm{~kg}$ ] for conventional wheat) depending on the wheat variety cultivated and the quality class (IP-Suisse, 2017). IP-Suisse has some further production guidelines on the level of wheat production as well as the farm-level that go beyond governmental cross-compliance requirements. Regarding wheat production, for example, growing stubble wheat (wheat after wheat) is forbidden in order to prevent the outbreak of diseases. Moreover, the application of herbicides containing the active substances (AS) dicamba, 2.4D, MCPA and MCPB are not permitted (IP-Suisse, 2016). Yet, herbicide application is in general still allowed on Extenso fields. The participation in IP-Suisse programs requires compliance with some farm-level rules on sustainable agricultural production (e.g. on animal husbandry or on genetically modified organisms). It therefore presents a production form in between intensive (i.e. conventional) and organic production. For wheat production under the Extenso programme, yields have been found to be lower and slightly more volatile ${ }^{3}$, but profits are higher than for intensive production, especially due to the agrienvironmental direct payment (e.g. Finger, 2014). Besides direct payments for the Extenso programme, Swiss farmers can apply for several, additional agri-environmental direct payments (see e.g. Huber et al., 2017). Especially important for this paper are the so-called soil preservation payments that are linked to the tillage system (Table 1). For no-till/direct sowing cultivation, the payment is CHF 250/ha. For mulch tillage (only flat tillage), the payment is CHF 150/ha. If farmers take part in a reduced tillage system they can get an additional CHF 400/ha (as of 2018) by not applying herbicides between harvesting the previous crop to harvesting the main crop - in our case winter wheat. These payments are not made if maize was sown before wheat. ${ }^{4}$ This exception is motivated by the fact that tillage in this situation is usually required to reduce problems of Fusarium and associated deoxynivalenol (DON) contents ${ }^{5}$. This will constitute an important constraint in our optimization model.

\footnotetext{
${ }^{2}$ This equals about $€$ 360/ha at an average exchange rate of 1.11 for 2017 (Eurostat, 2018). The standard (i.e. average) net profit of conventional wheat cultivation including direct payments were CHF 2652/ha and of Extenso wheat cultivation with IP-Suisse participation CHF 2981/ha (Boessinger et al., 2015).

${ }^{3}$ More specifically, Finger (2014) shows for the period 2001-2008 that mean yields for intensive and extensive wheat are $66 \mathrm{dt} / \mathrm{ha}$ vs. $50 \mathrm{dt} / \mathrm{ha}$, respective standard deviations of yields are $8.17 \mathrm{dt} / \mathrm{ha} \mathrm{vs.} 7.48 \mathrm{dt} / \mathrm{ha}$. Note, however, that large differences appear across varieties.

${ }^{4}$ Additionally, no soil preservation payments are paid if triticale or wheat is cultivated before wheat. The latter case is, however, not allowed under IP-Suisse growing regulations.

${ }^{5}$ Note that the here assumed restrictions (i) no wheat after wheat, ii) no wheat after maize if reduced or no-tillage was used) are made on the ground that a) the Extenso wheat production guidelines are binding for a large share of Swiss wheat producer and $b$ ) that Swiss arable farming is characterized by wide crop rotations. For example, cross compliance obligations require that at least 4 different crops (each with at least $10 \%$ of the acreage) are produced in one year (Bundesrat 2019).
} 
Note that in Switzerland, no genetically modified herbicide resistant crops are cultivated, which would imply within-season use of glyphosate. Moreover, pre-harvest use of glyphosate (desiccation) is not allowed in Switzerland. Thus, glyphosate is only used for pre-season weed control.

Pesticides play an important role in current policy discussion in Switzerland. A National Action Plan on pesticides has been introduced in 2016 that formulates clear targets (i.e. a 50\% reduction of risks) but also presents various approaches to reduce pesticide related risk for the environment and human health (see Bundesrat 2017). These comprise education and information approaches but also incentive schemes. More specifically, the support for practices that reduce pesticide risks. As an example, we here consider a payment scheme for herbicide-free production combined with reduced tillage. Moreover, two popular initiatives will be upon vote in Switzerland that address pesticides (Huber and Finger, 2019). The first initiative proposes to ban all synthetic pesticides. The second proposes to pay direct payments only to those farmers who do not use (synthetic) pesticides and comply with additional restrictions regarding the use of antibiotics and livestock density.

One of the largest problems regarding pesticide use in Switzerland currently is that thresholds in water bodies are exceeded frequently, especially for small rivers and creeks. For example, the study of Munz et al. (2012) shows that in more than $70 \%$ of 565 waterbodies above threshold concentrations of pesticides have been measured, with herbicides being the dominant type of pesticides therein. Similar results were obtained by other studies like Doppler et al. (2017), Wittmer et al. (2014) and Spycher et al. (2018) who also find especially herbicides to exceed threshold concentrations in Swiss small Swiss rivers. This problem also holds for glyphosate and its metabolite AMPA (Hanke et al., 2010, Huntscha et al., 2018, Poiger et al., 2017). Based on these observations, the above indicated political and industry actions have been initiated - motivating the here presented research.

Table 1. Agri-environmental payments for reduced tillage (soil preservation payments) ${ }^{\mathrm{a}}$

\begin{tabular}{|c|c|c|c|c|}
\hline Tillage system & $\begin{array}{l}\text { Direct } \\
\text { payment }\end{array}$ & $\begin{array}{l}\text { Herbicide } \\
\text { used after } \\
\text { sowing? }\end{array}$ & $\begin{array}{l}\text { Additional } \\
\text { payment for not } \\
\text { using herbicides }\end{array}$ & $\begin{array}{l}\text { Sum of soil } \\
\text { preservation } \\
\text { payments }\end{array}$ \\
\hline \multirow{2}{*}{$\begin{array}{l}\text { No till/direct sowing } \\
\text { (with glyphosate up to } \\
1.5 \mathrm{~kg} / \mathrm{ha} \text { ) }\end{array}$} & \multirow[b]{2}{*}{ CHF 250/ha } & Yes & - & CHF 250/ha \\
\hline & & No & - & CHF 250/ha \\
\hline \multirow{2}{*}{$\begin{array}{l}\text { No till/direct sowing } \\
\text { (without glyphosate) }\end{array}$} & \multirow{2}{*}{ CHF 250/ha } & Yes & - & CHF 250/ha \\
\hline & & No & CHF 400/ha & CHF 650/ha \\
\hline \multirow{2}{*}{$\begin{array}{l}\text { Mulch tillage } \\
\text { (e.g. with chisel plough } \\
\text { and/or rotary harrow) }\end{array}$} & \multirow[b]{2}{*}{ CHF 150/ha } & Yes & - & CHF $150 /$ ha \\
\hline & & No & CHF 400/ha & CHF 550/ha \\
\hline $\begin{array}{l}\text { Mulch tillage } \\
\text { (e.g. with chisel plough }\end{array}$ & & Yes & - & CHF 150/ha \\
\hline $\begin{array}{l}\text { and/or rotary harrow } \\
\text { and glyphosate } \\
\text { application) }\end{array}$ & CHF 150/ha & No & - & CHF $150 / \mathrm{ha}$ \\
\hline
\end{tabular}




\begin{tabular}{lllll}
\hline \multirow{2}{*}{ Mouldboard plough } & - & Yes & - & CHF 0/ha \\
& & No & - & CHF 0/ha \\
\hline
\end{tabular}

${ }^{a}$ The payments are not paid if maize was the previous crop. Note that payments reflect the situation as of 2018.

\section{Methodology}

The bio-economic modelling approach used here focusses on weed control in wheat production only and consists of the following steps: i) we specify mean and variability of the weed pressure and wheat yield potentials spatially explicitly, ii) we derive yield effects of weeds on wheat yields if untreated, iii) we obtain weed control strategies and their efficacy and costs, iv) we use a spatially explicit economic decision model to derive optimal weed control strategies under different scenarios, v) we assess the derived strategies in terms of economic losses, yield reductions and environmental impacts. The bioeconomic model used in our analysis is based on the modelling approach of Böcker et al. $(2018,2019)$, who applied a similar model to investigate the effects of a glyphosate ban in maize production in NorthRhine-Westphalia, Germany. Note that the model code, documentation and its data are accessible in an accompanying open code model publication (Böcker and Finger, 2018). Our research set-up was accompanied by expert interviews and expert feedback at different stages of the research process, i.e. from assumptions on weed control strategies and specific parameters until plausibility checks of model runs and interpretation of results.

We use this model to first simulate weed control decisions under current conditions, i.e. without any restrictions on glyphosate and herbicide use. Next, we simulate effects of two scenarios: i) a prohibition of glyphosate use and ii) a prohibition of all herbicides in Extenso wheat production. Based on the modelled adjustments in weed control measures by farmers, we particularly derive implications for farmers' net profitability, crop yields and environmental impacts of production. The level of analysis are all regional units in Switzerland that i) are potentially suited for cultivating cereals and ii) that grew Extenso winter wheat in the period 2008-2017. Combining these two criteria resulted in $m=1, \ldots, 1166$ regional units of the Swiss land use map (Figure A1; Federal Office for Agriculture, 2009).

\subsection{Modelling approach}

The goal function underlying the model assumes that farmers in each regional unit $m$ maximise expected utility $(E U)$ from stochastic net profits $(\tilde{\pi})$ from winter wheat cultivation:

$$
\max E U(\tilde{\pi})=\sum_{m=1}^{M} \sum_{t=1}^{T} E U\left(\tilde{\pi}_{m, t}\right) \cdot \rho_{t}
$$

In this function, $\rho_{t}$ is the probability that a certain attainable yield occurs in year $t$, over the simulation horizon $t=1, \ldots, T$. The chosen expected utility maximization framework allows to incorporate farmers 
risk preferences. The decision variables considered are pre- and post-sowing weed control strategies that will be introduced below. We choose a negative exponential utility function, which incorporates constant absolute risk aversion (Hardaker et al., 2004: 103):

$$
E U\left(\pi_{m, t}\right)=1-e^{-\frac{r_{a}}{1000} * \pi_{m, t}}
$$

where $r_{a}$ symbolises the relative coefficient of risk aversion, which is scaled by 1000 (Hardaker et al., 2015: 91) and subject to sensitivity analyses. We assume a relative risk aversion coefficients of 2 , reflecting a risk averse decision maker (e.g. Hardaker et al., 2004; Gardebroek, 2006) ${ }^{6}$. Moreover we conduct a sensitivity analysis with a coefficient of 4 , reflecting the high heterogeneity in farmers risk aversion (Meraner and Finger, 2018).

Accounting for different pre- (index $g$ ) and post-sowing (index $h$ ) weed control strategies, net profit $\tilde{\pi}$ (i.e. contribution margin II), i.e. the revenue minus the variable cost and product specific fixed cost is:

$$
\tilde{\pi}=[\tilde{y} \cdot P+S(g, h)-c(g)-c(h)-c s(g, h)-c f(y)-c o]
$$

where $\tilde{y}$ is the stochastic yield, $P$ is the wheat price, $S(g, h)$ are the per hectare strategy-dependent subsidies paid by the government, $c(g)$ and $c(h)$ the pre- and post-sowing weed control costs. $c s(g, h)$ are costs for sowing depending on the pre-sowing weed control strategy, $c f(y)$ are yield dependent costs for fertiliser, harvest, transport and ensiling, and co are other cost.

The yield realisations $\tilde{y}_{m, t, g, h}$ depend on the attainable yield, the weeds occurring in a regional unit, the weed pressure and applied weed control strategies. More specifically, the yield depends on an output damage control approach where weed control strategies decrease damage compared to the yield distribution possible without weed pressure (Böcker et al., 2018; Bosnic and Swanton, 1997a; Lichtenberg and Zilberman, 1986; Hall and Norgaard, 1973). The production function focussed on the production effects of weed control is defined as follows:

\footnotetext{
${ }^{6}$ The chosen functional form is less flexible than a power utility function, but has the advantage that negative net profits, which occur in our analysis, can be considered.
} 


$$
\left.\tilde{y}_{m, t, g, h}=\left(1-e^{-\left(\alpha_{0}+\alpha_{1} \cdot v_{m, j}\right)^{2}}\right) \cdot \tilde{y}_{m, t}^{a} \cdot\left[1-I \cdot \frac{e^{-\left(\beta_{0}+\beta_{1} \cdot z_{m, j}\right)^{2}}}{100 \cdot\left(e^{C \cdot \psi_{m, t}}+I \cdot \frac{e^{-\left(\beta_{0}+\beta_{1} \cdot z_{m, j}\right)^{2}}}{A}\right.}\right)\right]
$$

The first part accounts for the pre-sowing weed control activities, $\tilde{y}_{m, t}^{a}$ is the attainable yield for a regional unit (out of the 1166) and is treated as stochastic variable. The third part accounts for postsowing weed control (see data section for specifications). The latter is based on Cousens (1985) rectangular hyperbolic model, where $e^{-\left(\beta_{0}+\beta_{1} \cdot z_{m, j}\right)^{2}}$ is the yield loss based on different control strategies (denoted further as $D$ ). Parameter $\Psi$ represents the time of weed emergence in relation to the crop emergence (in days advantage), which reflects the overall weed pressure in the growing season. Parameters $A, C$ and $I$ are non-linear regression parameters: $I$ is the percent yield loss as $D$ approaches $0, A$ is the percent yield loss as $D$ approaches infinity and $C$ is the rate at which the yield loss $I$ decreases as $\Psi$ becomes larger (Bosnic and Swanton, 1997b). The parameter values $\mathrm{A}=0.931, \mathrm{C}=0.109$ and $\mathrm{I}=$ 0.006 were determined with the non-linear regression approach of Bosnic and Swanton (1997b), based on data of O'Donovan et al. (1985). The parameters $\alpha_{0}, \alpha_{1}, \beta_{0}$ and $\beta_{1}$ are to be estimated (see section $3.2)$.

We consider the stochasticity of attainable yield levels due to the stochasticity in weather conditions as main risk factor (following Böcker et al., 2019, see also Tembo et al., 2008). ${ }^{7}$ The stochasticity of attainable yield levels implies that the marginal value of product of weed control efforts early in the growing season are uncertain. Also the weed pressure $\Psi$ is stochastic, but can be observed by the farmer before weed control measures are taken. Weed control is thus state-contingent. To reflect the heterogeneity of weed pressure we perform sensitivity analyses with different $\Psi$-values. Wheat quality (with respect to baking quality) is the main driver of price risks (Swiss Granum, n.d.), motivating additional sensitivity analysis.

The parameters $v_{m, j}$ and $z_{m, j}$ in Eq. (4) are the pre- and post-sowing weed control effects based on the weed pressure in the growing season:

$$
\begin{aligned}
& v_{m, j}=\sum_{i}^{I} w_{m, i} \cdot a_{i} \cdot g_{j, i} \\
& z_{m, j}=\sum_{i}^{I} w_{m, i} \cdot a_{i} \cdot h_{j, i}
\end{aligned}
$$

\footnotetext{
${ }^{7}$ Note that due to the non-availability of distributions of attainable yields, an indirect approach was chosen and is outlined in section 4 .
} 
where $w_{m, i}$ is a dummy if weed $i$ occurs in regional unit $m, a_{i}$ is the average abundance if a weed is not controlled and acts as a measure for its yield reducing effect. Moreover, $g=1, \ldots, G$ and $h=1, \ldots, H$ represent the efficacies of the different weed control strategies $j$ against each weed $i[0,1]$.

The share of the pre- and post-sowing weed control strategies, i.e. $S_{g, m, t}$ and $S_{h, m, t}$ (Eq. 6), are the decisions variables. Additionally, the vector $\varphi_{g, h, s c e n}$ contains either 1 or 0 reflecting scenarios in which different herbicides are allowed to be applied or not:

$$
\pi_{m, t}=\sum_{g=1}^{G} \sum_{h=1}^{H} \pi_{m, t, g, h} \cdot S_{g, m} \cdot \varphi_{g, h, s c e n} \cdot S_{h, m}, \quad S_{g, m}, S_{h, m}, \varphi_{g, h, s c e n} \in \mathbb{R}=[0,1]
$$

\subsection{Parameterisation}

The parameters $\alpha_{0}, \alpha_{1}, \beta_{0}$ and $\beta_{1}$ in Eq. (2) are estimated by minimising the error term between the simulated yield levels $E\left(y_{m, t, g, h}\right)$ and the average observed yield levels $\bar{y}_{m, t}$ (Böcker et al., 2018). This estimation is performed nine times for each of the parameters (in total 9 x $4=36$ parameters), where each of the nine runs parameterizes the variables for a different landscape and soil category in the Swiss land use map (Figure A1). For each of the nine runs only those regional units are used, which fall into the respective category, according to the land use map:

$$
\min \varepsilon=\sum_{m=1}^{O b s M} \sum_{t=2010}^{2013}\left(\frac{E\left(y_{O b s m, t, g, h}\right) \cdot \dot{S}_{t, \text { Obsm }, g} \cdot \dot{S}_{t, \text { obsm }, h}}{\sum_{g, h}\left(\dot{S}_{t, \text { Obsm }, g} \cdot \dot{S}_{t, \text { Obsm }, h}\right)}-\bar{y}_{O b s m, t}\right)^{2}
$$

In this equation, $O b s M$ are those regional units of which the yearly used weed control strategies in Extenso winter wheat are known. This information comes from field-level data of the Swiss AgriEnvironmental Data Network of the Agroscope Research Station (see data section 4). $\dot{S}_{t, o b s m, g}$ and $\dot{S}_{t, O b s m, h}$ are the selected pre- and post-sowing weed control strategies that were applied in regional unit $O b s m$ and in year $t$. The $\Psi_{m}$-values in Eq. (2) were estimated according to the approach of Böcker et al. (2019). We use growing days, which is the number of days of growing advantage, that weeds have over wheat, (given a certain minimum temperature is reached) to depict phenology development. ${ }^{8}$ Growing advantage is computed for each of the considered weeds.

\subsection{Simulation and Analysis}

The model is solved using the non-linear solver 'conopt' in the General Algebraic Modelling System (GAMS; https://www.gams.com/). The modelling process starts with the simulation of a reference scenario representing current conditions. Next, scenarios for i) glyphosate-free and ii) herbicide-free

\footnotetext{
${ }^{8}$ This approach was chosen instead of growing-degree-days (which summarise over a temperature sum if a certain minimum temperature is achieved), to harmonise with the modelling of the competitive advantage of weeds over wheat.
} 
wheat cultivation are simulated, i.e. the respective strategies are taken out of the set of available strategies of farmers. Then, the differences with respect to a wide range of indicators between the reference scenario and the glyphosate- and herbicide-free scenarios are calculated. In the main body of this article, we present changes of the plant protection strategies, the net profit, changes in yield levels and changes in environmental risks due to weed control measures taken. We follow Böcker et al. (2019) and analyse two environmental dimensions relevant for pesticide application. First, we use the Pesticide Load Indicator (Kudsk et al., 2018) as an indicator of potential adverse effects of pesticides on human health and the environment. The Pesticide Load Indicator is a generic pesticide risk indicator, which summarises potential, adverse effects of pesticides in three spheres: environmental toxicity (e.g. effects on earthworms, mammals, fish, algae, etc.), environmental fate (e.g. the biodegradability of the products) and human health and can be calculated for all authorized pesticides (here herbicides). The unit is Load/ha and the indicator was recently applied for Swiss wheat production by Möhring et al. (2019). Load values for selected active ingredients are documented in Table A2 in the appendix. For a complete overview of Load values for all strategies see Böcker and Finger (2018b). Second, we consider the energy balance as a measure of the overall energy consumed by the agricultural system. In the energy balance, all physical material flows of wheat cultivation are traced (Hülsbergen et al., 2001), i.e. is the difference between consumed and output energy of the system That means, direct (e.g. diesel consumption) and indirect energy consumption (e.g. production energy for machinery or for pesticides) is calculated, which sum up to total energy consumption. Furthermore, the energy output is calculated which is the energy of the cultivated wheat. The unit is here MJ/ha (see Böcker et al., 2019, for further details).

A large scale sensitivity analysis is conducted in the modelling process to check the validity of our results under changing environmental conditions and preferences. For each change in a parameter (i.e. scenario) we therefore perform a new model run. First, we use different abundance values $a_{i}$ in Eq. (5). The abundance is in our approach modelled as state-contingent, but depends in reality, among others, also on the previous crop and the previous tillage system (Streit et al., 2003). Here, we include different values for three tillage systems (conventional tillage, mulch tillage and no tillage) and 2 different values for the previous crop (average and maize). Second, three different weed pressures $\Psi$ (low: $\Psi=9$, medium: $\Psi=4$ and high: $\Psi=-1$ ) are simulated. The chosen $\Psi$-values 9,4 and -1 are the 5\%, 50\% and 95\%percentiles of the calculated $\Psi$-values in the parameterization. Third, in order to control for Fusarium and associated deoxynivalenol (DON) contents in grains, mouldboard ploughing has to be done to reduce growth of this fungi (Kirchmeier and Demmel, 2007; Zorn et al., 2018). Based on expert interviews and observed farming practices (see data section 4), we consider this aspect in the model by implementing a restriction that mouldboard ploughing might to be done pre-sowing in $50 \%$ of the area, in addition to a $0 \%$ scenario. The $50 \%$ - restriction reflects that every second time a farmer grows winter wheat he or she would need to plough before sowing. Fourth, we simulate two variants of the productiondependent soil preservation payments (scenarios: with and without payment, see Table 1). Fifth, we 
include two different risk-aversion parameters. In each scenario we test if changes in outcome variables are significantly different from zero, using nonparametric Wilcoxon-Mann-Whitney-tests.

In the results section, the text focusses on results for a medium weed pressure, average abundance and assume that conventional tillage was applied in the years before the investigated growing period.

\section{Data}

We consider in our analysis the 21 most important weed species in Swiss wheat production systems, selected according to Streit et al. (2003) and Gehring (2003) (see Table 2). To approximate weed pressure we use data on the general regional abundance of weeds and average weed presence in percent, given the soil type. Data on regional weed species abundance in Switzerland is based on observational data provided by Info Flora (2018). The data is provided as point observations in a $1 \mathrm{x} 1 \mathrm{~km}$ raster, which was fitted to the considered regional units. We create binary variables if weed $i$ is located in regional unit $m$. In order to guarantee good data quality, we exclude regional units from our simulations with too few weed observations, so that we finally consider a number of 1166 regional units. ${ }^{9}$ Information on the presence of different weed species on three different soil types suitable for wheat production in Switzerland was taken from Streit et al. (2003) and from Gehring (2003). Based on the soil type, they differentiate three different farming systems in their analysis (no tillage, mulch tillage and conventional tillage) and give average values of weed presence for each of the systems. If a weed species is not present in the region, according to Info Flora (2018) it was not considered, respectively.

Table 2. Average degree of presence [\%] of different weeds on three main soil types in wheat cultivation

\begin{tabular}{|c|c|c|c|c|}
\hline Weed species & $\begin{array}{c}\text { Code of weed } \\
\text { (European and } \\
\text { Mediterranean } \\
\text { Plant } \\
\text { Protection } \\
\text { Organization) }\end{array}$ & $\begin{array}{c}\text { Light to } \\
\text { medium soils }\end{array}$ & $\begin{array}{l}\text { Medium to } \\
\text { heavy soils }\end{array}$ & Heavy soils \\
\hline Alopercurus myosuroides & ALOMY & 1 & - & 41 \\
\hline Apera spica-venti & APESV & 22 & - & 2 \\
\hline Bromus spp. (B. hordeaceus and B. sterilis) & BROMO & - & - & 1 \\
\hline Elymus repens & AGRRE & 1 & - & - \\
\hline Lolium spp. (L. perenne) & LOLPE & 1 & - & - \\
\hline Роа аппиа & POAAN & 4 & - & - \\
\hline Brassica napus & BRSNN & 1 & - & 2 \\
\hline Capsella bursa-pastoris & CAPBP & 1 & 1 & 1 \\
\hline Centaurea cyanus & CENCY & 1 & - & - \\
\hline Cirsium arvense & CIRAR & - & 1 & - \\
\hline Galeopsis tetrahit & GAETE & 2 & 1 & 1 \\
\hline
\end{tabular}

\footnotetext{
${ }_{9}^{9} 2199$ regional units are potentially suitable for cereal production. Many of the excluded polygons with limited data availability are, however, very small.
} 
Galium aparine

Lamium purpureum

Matricaria spp. (M. chamomilla)

Myosotis arvensis

Papaver rhoeas

Polygonum convolvulus

Raphanus raphanistrum

Stellaria media

Veronica spp. (V. hederifolia)

Viola arvensis
GALAP

LAMPU

MATCH

MYOAR

PAPRH

POLCO

RAPRA

STEME

VERHE

VIOAR
17

3

8

5

$-$

1

1

12

7

15

$\begin{array}{rr}\mathbf{5 6} & \mathbf{1 9} \\ 7 & 5 \\ 4 & 5 \\ 3 & 2 \\ - & 2 \\ 3 & 1 \\ 1 & - \\ 7 & 6 \\ 10 & 8 \\ 5 & 5\end{array}$

19

1

6

5

Reference: Gehring (2003)

We define three soil types in our study: light, medium and heavy soils. For each regional unit, a certain main weed species and a certain degree of presence is defined. Weed species in bold reflect the most important weeds for winter wheat production on the different soil types.

We consider currently used pre- and post-sowing weed control strategies, but also account for strategies currently not used. Overall, 26 different pre-sowing and 114 post-sowing strategies are included. Pre-sowing weed control strategies comprise one or several passes of non-inverting tillage, mouldboard ploughing, glyphosate application with or without tillage and alternative strategies such as weed flaming and catch crop cultivation (e.g. Wittwer et al., 2013) with direct tillage (see online Appendix A for an overview of all strategies). For the post-sowing period, 114 different strategies are considered, including one or two passes of selective herbicide application, one or more passes of comb harrowing, combinations of comb harrowing and selective herbicide application and undersown crops (Brust et al., 2011). Alternative strategies such as hand-weeding and robot weeding were initially considered but were not included (and never among the optimally chosen weed control options) because of high labour costs, the lack of market-ready weeding robots and because of the difficulties arising with the narrow spacing of cereals. Note that the here considered strategies also comprise multiple nonchemical weed control approaches. Depending on the intensity of mechanical weed control (e.g. with respect to tillage intensity, number of times a harrow is used etc.), yield losses due to weed pressure as well as the arising costs differ substantially. The set of optimal weed control strategies, is a key output of our bio-economic model.

Data provided from the Swiss Central Evaluation of Agri-environmental Indicators of the Agroscope Research Station was used to i) derive insights in typical weed control strategies and ii) to parameterise our model (e.g. Eq. 7). This data consists of field-level information on crop management (e.g. including tillage, seeding, fertilisation, and pesticide application) (see also Spycher et al., 2013; Möhring et al., 2019). For Extenso wheat, data from 108 farms (reflecting 75 regional units of our analysis) over the period 2009-2013 was used.

Spatially distributed attainable yield information for Extenso winter wheat is not available for Switzerland. We thus used an indirect approach to account for attainable yields and their variability. To this end, we use yearly quantities of delivered wheat on a municipality level, as provided by the producer organisation IP-Suisse for the period 2008-2017. We transform the municipality-level yields to 
regional-level units (see Figure A1) using operations of the geographic information systems ArcGIS. To estimate the attainable yield level, we use a three year moving average and add an additional $7 \%$ ( $2 \%$ for sprout losses and an additional 5\% for current yield losses due to weeds in line with Boessinger et al., 2015 and Oerke, 1994: 262), in order to account for the gradient of the yield function. Not adding current yield losses would imply that we calculate strategy choices at a lower point of the yield function with higher marginal returns of weed control, which are not realistic. Using this procedure, the attainable yield levels between the regional units range between $32 \mathrm{dt} / \mathrm{ha}$ and $69 \mathrm{dt} / \mathrm{ha}$ expressed as average over the years 2008-2017. The mean and median attainable yield levels over all regional units are $52 \mathrm{dt} / \mathrm{ha}$.

Relevant cost parameters for weed control strategies and other activities and inputs are taken from Gazzarin (2017), Fenaco (2018) and Boessinger et al. (2015). The most relevant cost parameters are depicted in Table 3 (see Böcker and Finger, 2018b, for further details). .

Please find a detailed description of all data sources and information on data availability in Table A1 in the Appendix. 
Table 3. Economic parameters in the model and assumed machinery equipment

\begin{tabular}{|c|c|c|c|}
\hline $\begin{array}{c}\text { Sub- } \\
\text { activity }\end{array}$ & $\begin{array}{l}\text { Work hours } \\
\text { (wage: } \\
\text { CHF 28/h) } \\
\end{array}$ & Fix costs & $\begin{array}{l}\text { Variable costs } \\
\text { (diesel: } \\
\text { CHF 1.54/1 }\end{array}$ \\
\hline \multicolumn{4}{|c|}{ Weed control-related activities: } \\
\hline Tractor $(82 \mathrm{~kW})$ & - & CHF $20.25 / \mathrm{h}$ & $\begin{array}{r}\mathrm{CHF} 4.95 / \mathrm{h}+ \\
9.84 \mathrm{l} / \mathrm{h}\end{array}$ \\
\hline Chisel plough $(3 \mathrm{~m})^{\mathrm{a}}$ & $1.40 \mathrm{ha} / \mathrm{h}$ & CHF 29.04/ha & CHF 6.82/ha \\
\hline Rotary harrow with furrow press $3 \mathrm{~m})^{\mathrm{a}}$ & $1.09 \mathrm{ha} / \mathrm{h}$ & CHF 67.20/ha & CHF $21.00 /$ ha \\
\hline Mouldboard plough (3 furrows) ${ }^{a}$ & $0.47 \mathrm{~h} / \mathrm{ha}$ & CHF 65.57/ha & CHF 34.94/ha \\
\hline Furrow press (for plough) & - & CHF $17.67 /$ ha & CHF 8.31/ha \\
\hline Comb harrow $(6 \mathrm{~m})$ & $3.95 \mathrm{~h} / \mathrm{ha}$ & CHF 16.22/ha & $\mathrm{CHF} 4.01 / \mathrm{ha}$ \\
\hline Field sprayer incl. preparation $(15 \mathrm{~m})$ & $3.58 \mathrm{ha} / \mathrm{h}$ & CHF $17.35 /$ ha & CHF 5.88/ha \\
\hline \multicolumn{4}{|c|}{ Other activities: } \\
\hline Drill (3m) & $1.60 \mathrm{ha} / \mathrm{h}$ & CHF $42.10 /$ ha & CHF 7.36/ha \\
\hline Direct drill (3m) & $1.50 \mathrm{ha} / \mathrm{h}$ & CHF $47.40 /$ ha & CHF $21.60 /$ ha \\
\hline \multicolumn{2}{|c|}{$\begin{array}{l}\text { Seed (higher costs when } \\
\text { comb harrow is used } \\
\text { Zimdahl, 2013: } 281 \mathrm{f} .)\end{array}$} & $\begin{array}{l}\text { CHF 226.80/ha } \\
\text { CHF 252.00/ha }\end{array}$ & \\
\hline Mounted fertiliser spreader (3x) & $1.1 \mathrm{ha} / \mathrm{h}$ & CHF 6.60/ha & CHF 2.69/ha \\
\hline $\mathrm{N}^{\mathrm{b}}$ & & & CHF $1.60 / \mathrm{kg}$ \\
\hline $\mathrm{P}_{2} \mathrm{O}_{5}{ }^{\mathrm{b}}$ & & & $\mathrm{CHF} 1.43 / \mathrm{kg}$ \\
\hline $\mathrm{K}^{\mathrm{b}}$ & & & CHF $0.89 / \mathrm{kg}$ \\
\hline Combine harvester $(4.8-5.2 \mathrm{~m})$ & $1.43 \mathrm{ha} / \mathrm{h}$ & CHF $235.34 / \mathrm{h}$ & $\begin{array}{r}\text { CHF } 69.83 / \mathrm{h}+ \\
27.00 \mathrm{l} / \mathrm{h}\end{array}$ \\
\hline Cutterbar $(4.8-5.2 \mathrm{~m})$ & - & CHF $37.14 / \mathrm{h}$ & CHF $12.19 / \mathrm{h}$ \\
\hline Three-way tipper (100dt) & $1 \mathrm{load} / \mathrm{h}$ & CHF 0.40/dt & CHF $0.13 / d t$ \\
\hline
\end{tabular}

Source: Böcker et al. (2018b); Gazzarin (2017); Boessinger et al. (2015).

${ }^{\text {a }}$ On heavy soils, diesel consumption for mouldboard ploughing is $30 \%$ higher, on light soils, it is $30 \%$ lower. For chisel ploughing and rotary harrowing, a factor of $20 \%$ is used (Böcker et al., 2018).

${ }^{\mathrm{b}}$ Only the yield-dependent fertilisation costs are included in our calculations. If a higher yield is achieved, higher fertilisation costs arise. Other fertilisation costs are excluded, because we do not know the soil nutrient content and we do not know the type of fertilisation (artificial or organic fertiliser). The calculated net profits are therefore slightly higher than in reality. 


\section{Results}

The consequences of the adoption of glyphosate-free and herbicide-free Extenso wheat production systems are presented in two sub-sections. First, we present results, assuming no soil preservation payments (and related direct payments for herbicide-free production, see Table 1). Second, we show model outcomes, when farmers are allowed to opt for one of the current soil preservation payments. In both sections, we present economic results in terms of changes in net profits, price mark-ups (on wheat prices) needed to compensate higher production costs and estimated yield changes - and environmental impacts in terms of Pesticide Load and energy usage (for a detailed description of environmental impacts also see Figure A3 and A4 of online Appendix B).

\subsection{Glyphosate-free (a) and herbicide-free (b) wheat cultivation without soil preservation} payments

The optimal weed control strategies for two selected scenarios, i.e. with and without ploughing restriction are shown in Table 4 and 5. In the text, we focus on results for a medium weed pressure, average abundance and assume that conventional tillage was applied in the years before the investigated growing period. However, we present a wider range of weed pressure scenarios in the Figures presented in this section. We find that in absence of agri-environmental direct payments for soil preservation (and accompanied direct payments for non-use of herbicides), the application of glyphosate, combined with direct sowing of winter wheat, is under current conditions the optimal, i.e. utility maximising, presowing strategy in the majority of regional units. If the mouldboard plough does not need to be used (scenario plough $0 \%$ ), applying glyphosate is optimal in about $95 \%$ of the regional units. If glyphosate is excluded from the possibilities, non-inverting mechanical strategies are used as substitute. More specifically, one pass of chisel ploughing plus one pass of rotary hoeing are frequently used. Some few regional units, mainly those with very low attainable yield levels, also select direct sowing without weed control as an optimal strategy.

Table 5. Applied pre-sowing strategies (in \% share of regional units) in the reference, glyphosate-free and herbicide-free scenario

\begin{tabular}{|c|c|c|c|c|c|c|}
\hline \multirow[b]{2}{*}{ Scenario: } & \multicolumn{3}{|c|}{ Plough: $\min .50 \%$ use } & \multicolumn{3}{|c|}{ Plough: $\min 0 \%$ use } \\
\hline & Reference & $\begin{array}{c}\text { Glyphosate- } \\
\text { free }\end{array}$ & $\begin{array}{l}\text { Herbicide- } \\
\text { free }\end{array}$ & Reference & $\begin{array}{c}\text { Glyphosate- } \\
\text { free }\end{array}$ & $\begin{array}{c}\text { Herbicide- } \\
\text { free }\end{array}$ \\
\hline No pre-sowing weed control & $1.5 \%$ & $1.6 \%$ & $1.7 \%$ & $3.1 \%$ & $3.3 \%$ & $3.4 \%$ \\
\hline Cover crop + direct sowing & $0.0 \%$ & $0.0 \%$ & $0.0 \%$ & $0.0 \%$ & $0.0 \%$ & $0.0 \%$ \\
\hline Pure mechanical & $50.3 \%$ & $98.4 \%$ & $98.3 \%$ & $0.5 \%$ & $96.7 \%$ & $96.6 \%$ \\
\hline Partly mechanical & $50.3 \%$ & $98.4 \%$ & $98.3 \%$ & $0.5 \%$ & $96.7 \%$ & $96.6 \%$ \\
\hline No herbicides & $51.8 \%$ & $100.0 \%$ & $100.0 \%$ & $3.6 \%$ & $100.0 \%$ & $100.0 \%$ \\
\hline Herbicide/Glyphosate & $48.2 \%$ & - & - & $96.4 \%$ & - & - \\
\hline
\end{tabular}


Numbers in the table refer to shares (of the 1166 regional units) in which a particular strategy was chosen according to the bio-economic model. Results are presented for six different scenarios: reference, glyphosate-free and herbicide-free scenario under no restriction and under the restriction that $50 \%$ of the area is ploughed..

The optimal post-sowing weed control strategy usually comprises application of selective herbicides (in more than $95 \%$ of the regional units). More specifically, products containing the active substances Florasulam and Tritosulfuron are optimal in most of the locations (see Table 5). This is due to the low product price and the high efficacy against the important broad-leaved weed species including Galium aparine and Stellaria media. The glyphosate-free-scenario does not lead to a substitution with other selective herbicides in the post-sowing strategies. Only if all herbicides are excluded, mechanical weed control strategies are applied, consisting of one to three comb harrowing passes.

Table 5. Applied post-sowing strategies (in \% share of regional units) in the reference, glyphosate-free and herbicide-free scenario

\begin{tabular}{|c|c|c|c|c|c|c|}
\hline \multirow[b]{2}{*}{ Scenario: } & \multicolumn{3}{|c|}{ Plough: $\mathbf{5 0 \%}$} & \multicolumn{3}{|c|}{ Plough: 0\% } \\
\hline & $\begin{array}{l}\text { Refe- } \\
\text { rence }\end{array}$ & $\begin{array}{c}\text { Glyphosate- } \\
\text { free }\end{array}$ & $\begin{array}{c}\text { Herbicide- } \\
\text { free }\end{array}$ & $\begin{array}{l}\text { Refe- } \\
\text { rence }\end{array}$ & $\begin{array}{c}\text { Glyphosate- } \\
\text { free }\end{array}$ & $\begin{array}{c}\text { Herbicide- } \\
\text { free }\end{array}$ \\
\hline No post-sowing weed control & $2.8 \%$ & $2.8 \%$ & $6.1 \%$ & $3.1 \%$ & $3.2 \%$ & $6.2 \%$ \\
\hline Undersown crop & $0.0 \%$ & $0.0 \%$ & $0.0 \%$ & $0.0 \%$ & $0.0 \%$ & $0.0 \%$ \\
\hline Pure mechanical & $0.0 \%$ & $0.0 \%$ & $93.9 \%$ & $0.0 \%$ & $0.0 \%$ & $93.8 \%$ \\
\hline Partly mechanical & $0.0 \%$ & $0.0 \%$ & $93.9 \%$ & $0.0 \%$ & $0.0 \%$ & $93.8 \%$ \\
\hline No herbicides & $2.8 \%$ & $2.8 \%$ & $100.0 \%$ & $3.1 \%$ & $3.2 \%$ & $100.0 \%$ \\
\hline Herbicide & $97.2 \%$ & $97.2 \%$ & - & $96.9 \%$ & $96.8 \%$ & - \\
\hline Diflufenican & $7.5 \%$ & $7.4 \%$ & - & $7.4 \%$ & $7.3 \%$ & - \\
\hline Florasulam & $89.5 \%$ & $89.5 \%$ & - & $89.3 \%$ & $89.3 \%$ & - \\
\hline Flufenacet & $2.1 \%$ & $2.1 \%$ & - & $2.1 \%$ & $2.1 \%$ & - \\
\hline Pendimethalin & $0.1 \%$ & $0.1 \%$ & - & $0.1 \%$ & $0.1 \%$ & - \\
\hline Pinoxaden & $0.6 \%$ & $0.6 \%$ & - & $0.6 \%$ & $0.6 \%$ & - \\
\hline Tritosulfuron & $89.0 \%$ & $89.1 \%$ & - & $88.9 \%$ & $88.9 \%$ & - \\
\hline Others & $0.0 \%$ & $0.0 \%$ & - & $0.0 \%$ & $0.0 \%$ & - \\
\hline
\end{tabular}

Numbers in the table refer to shares (of the 1166 regional units) in which a particular strategy was chosen according to the bio-economic model. Results are presented for six different scenarios: reference, glyphosate-free and herbicide-free scenario under no restriction and under the restriction that $50 \%$ of the area is ploughed.

Figure 2 to Figure 6 summarize the main results of our simulations for both the glyphosate-free- and the herbicide-free-scenario (assuming no soil preservation payments). The median losses from excluding glyphosate from the production system are about CHF 36/ha assuming that a plough has to be used in 50\% of cases (for disease control) and CHF 71/ha if no plough has to be used (Figure 2). The maximum loss from switching to a glyphosate-free cultivation is CHF 119/ha. This reduction in net profits is mainly due to a yield reduction. More specifically, median yield losses are $0.8 \mathrm{dt} / \mathrm{ha}$ if $50 \%$ of 
the area is ploughed and of $1.6 \mathrm{dt} / \mathrm{ha}$ if no area has to be ploughed. More expensive alternative presowing weed control strategies, such as two passes of non-inverting tillage, contribute to lower net profits. If wheat is cultivated herbicide-free, we find a profit reduction of up to CHF 192/ha (Figure 4). In this scenario, a median yield reduction of $1.6-2.7 \mathrm{dt} / \mathrm{ha}$ is observed ( $3-6 \%$ of average yields).

Reductions in net profitability are highly heterogonous across space (e.g. Figure 5). Along these lines, Figure A2 shows the frequency and density distribution of the price mark-ups which would be required to compensate farmers for losses due to the non-use of herbicides. For a complete compensation of estimated financial losses (in all regional units), price mark-ups would have to be CHF 1.43/dt for glyphosate-free production and CHF 4.85/dt for herbicide-free production (not shown). Due to the high spatial heterogeneity, lower price mark-ups, however, would be sufficient to compensate the majority of farmers. 
Net profit reduction in glyphosate-free wheat cultivation

(mouldboard plough has to be used on $\underline{50 \%}$ of the area; conventional tillage previously)



(mouldboard plough has to be used on $\underline{0 \%}$ of the area; conventional tillage previously)

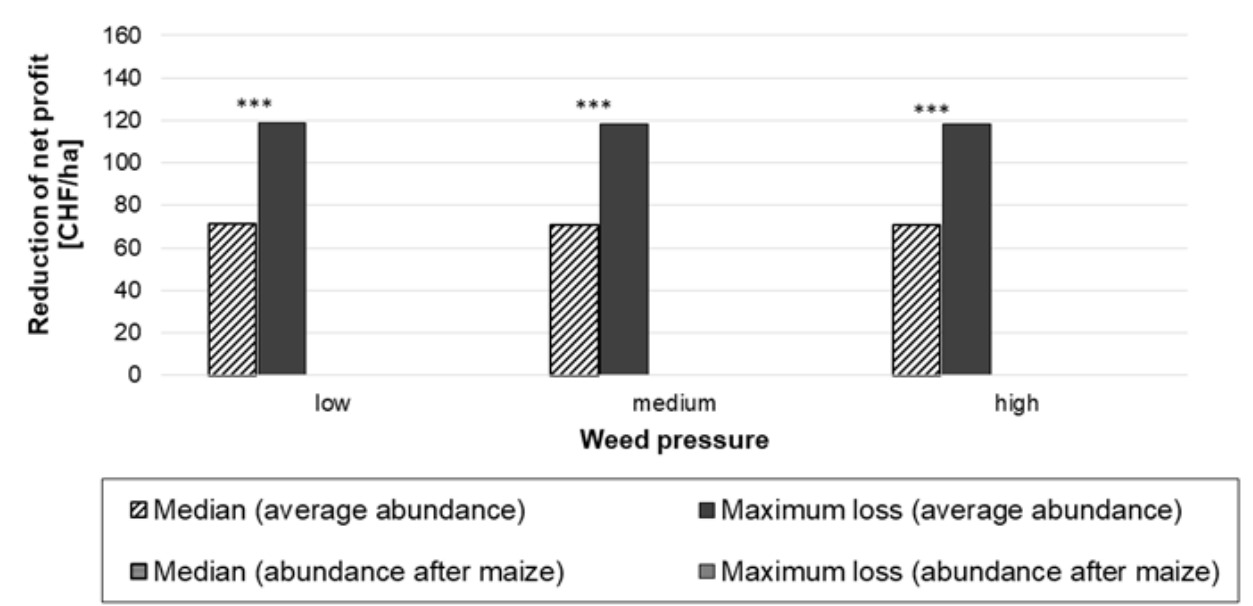

Figure 2. Reduction of net profit in glyphosate-free wheat cultivation for the scenarios with min. $50 \%$ ploughing and with no compulsory ploughing.

Note that in the $0 \%$ ploughing scenario (lower panel), there is no scenario 'abundance after maize' displayed as this should be avoided according to IP-Suisse guidelines (see section 2). Wilcoxon-Mann-Whitney-test is used to test for significant changes. ', *, **, *** and n.s. indicate the significance levels $10 \%, 5 \%, 1 \%, 0.1 \%$ and not significant.

Note: an earlier version of this figure is available in Böcker and Finger (2018a). 

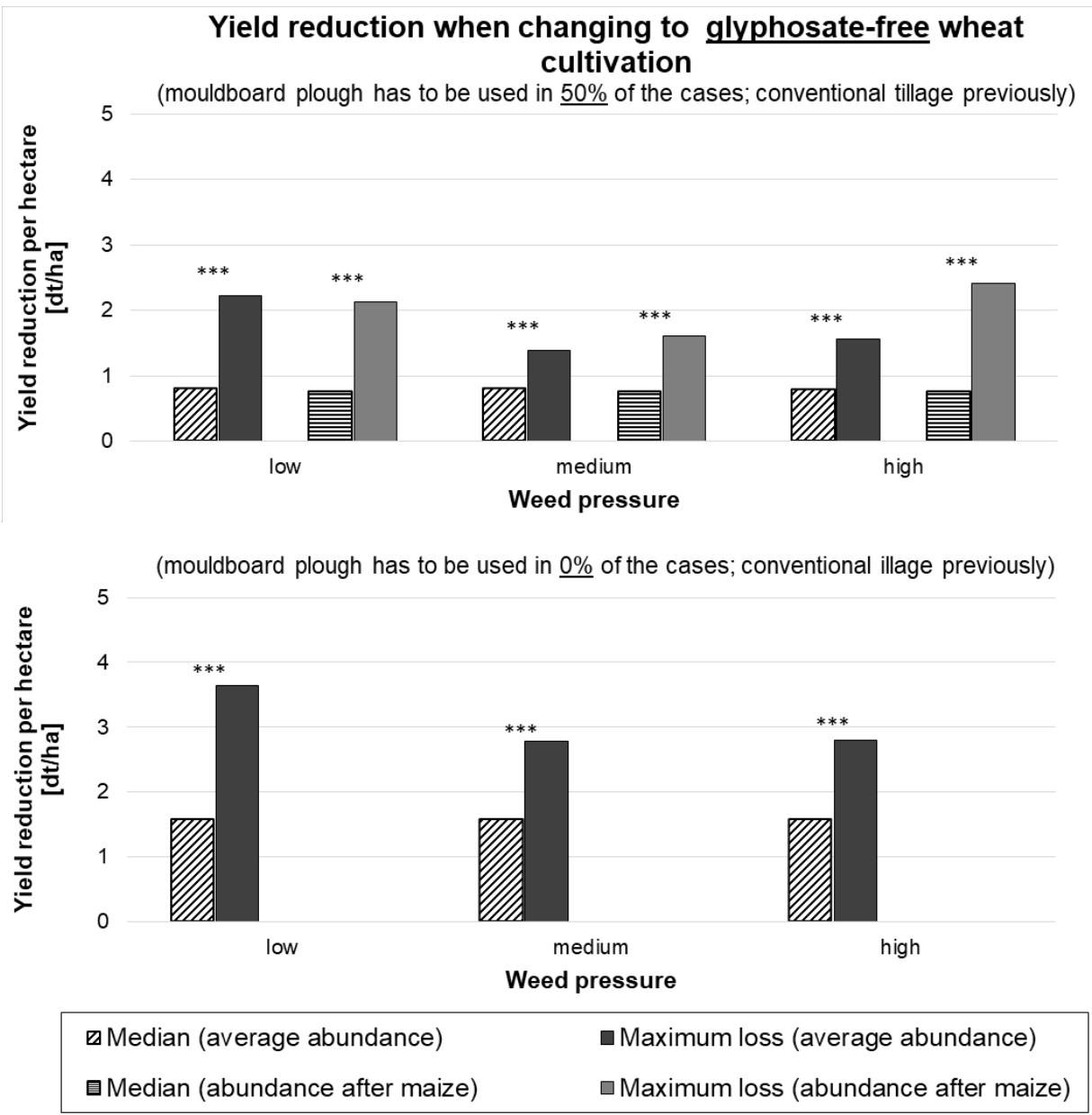

Figure 3. Median and maximum yield reduction for the scenarios with min. $50 \%$ ploughing and with no compulsory ploughing.

Note that in the $0 \%$ ploughing scenario (lower panel), there is no scenario 'abundance after maize' displayed as this should be avoided according to IP-Suisse guidelines (see section 2). Wilcoxon-Mann-Whitney-test is used to test for significant changes. ', *, **, *** and n.s. indicate the significance levels $10 \%, 5 \%, 1 \%, 0.1 \%$ and not significant.

Note: an earlier version of this figure is available in Böcker and Finger (2018a).

The substitution of glyphosate with mechanical weed control strategies leads to an overall reduction of human health and environmental risks from pesticide use as measured with the Load index. While the median of the total environmental pesticide load is 1.6 - 1.66 Load units/ha in all reference scenarios. Glyphosate-free production leads to a significant reduction of the Pesticide Load of $0.06-0.11 \mathrm{Load} / \mathrm{ha}$ (3.6-6.6\%, see also Figure A3 in online Appendix B). This reflects that glyphosate is not substituted with more intense (and more toxic) post-sowing herbicide applications. It also shows that post-sowing herbicides represent a much larger share of the total Load/ha (and thus of the overall environmental and human health risks due to pesticide use), compared to the substituted pre-sowing applications with glyphosate. A complete substitution of herbicide applications with mechanical strategies consequently leads to an additional reduction of the Pesticide Load of 1.55-1.6 Load/ha (100\% reduction to $0 \mathrm{Load} / \mathrm{ha}$, as no herbicides in Extenso wheat production are used in this scenario). Changes in the energy balance 
are ambiguous. We find a median decrease in energy consumption in the herbicide-free-scenario compared to the reference scenario, indicating a lower overall intensity of wheat cultivation. We, however, find a mean increase in energy consumption in this scenario (see also Figure A3 in online Appendix B). The differences in median and mean results are due to some regions, where substitution of herbicide application with mechanical weed control is relatively intense and heavy soils can be found. This consequently leads to higher diesel consumption.
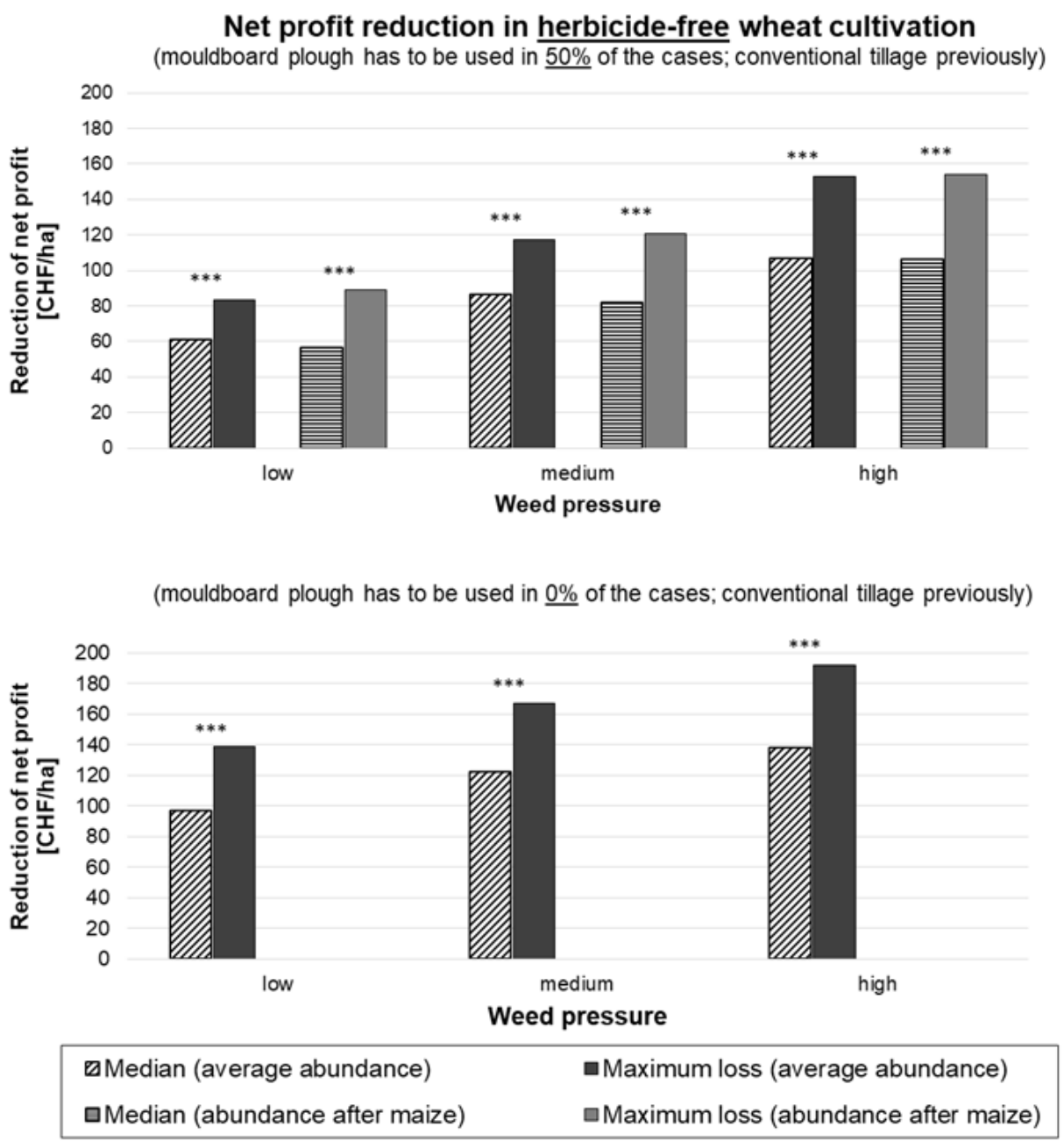

Figure 4. Reduction of net profit in herbicide-free wheat cultivation for the scenarios with min. $50 \%$ ploughing and with no compulsory ploughing.

Note that in the $0 \%$ ploughing scenario (lower panel), there is no scenario 'abundance after maize' displayed as this should be avoided according to IP-Suisse guidelines (see section 2). Wilcoxon-Mann-Whitney-test is used to test for significant changes. ', *,**,*** and n.s. indicate the significance levels $10 \%, 5 \%, 1 \%, 0.1 \%$ and not significant. 

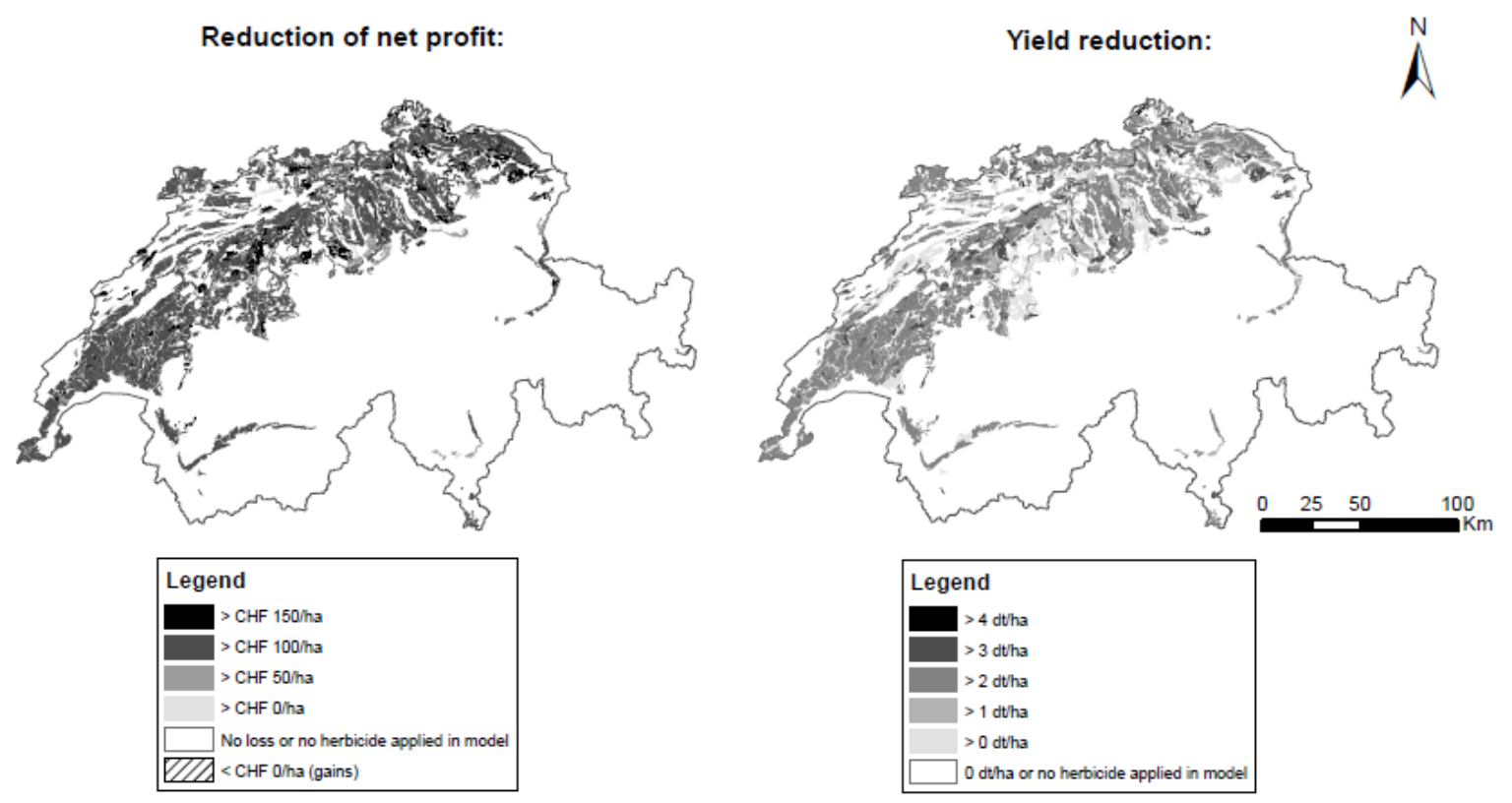

Figure 5. Spatial distribution of the net profit reduction and the reduction of yield in herbicide-free wheat cultivation. $^{\mathrm{a}}$

${ }^{\text {a }}$ Scenario with $\mathrm{P}=\mathrm{CHF} 58 / \mathrm{dt}$, high weed pressure, average abundance, conventional tillage in previous seasons. Note: an earlier version of this figure is available in Böcker and Finger (2018a).

\subsection{Glyphosate-free (a) and herbicide-free (b) wheat cultivation considering soil preservation payments}

Table 7 shows the optimal pre-sowing strategies for the reference scenario, when we account for the current soil preservation payments. We find that in most regions applying a mechanical strategy is optimal for pre-sowing and post-sowing in the reference scenario already - if a crop other than maize is grown before wheat, e.g. potatoes or sugar beet. ${ }^{10}$ As a result, the model simulates no significant change when glyphosate or all herbicides are excluded because herbicide-free wheat cultivation is already the optimal strategy in the reference scenario, due to soil preservation payments. As post sowing strategy, one to three passes of comb harrowing are selected by the model in all scenarios.

\footnotetext{
${ }^{10}$ If maize, wheat or triticale is cultivated the year before wheat, no soil preservation payments are paid at all. In that case the strategy selection resembles the ones in Table 4 and 5 .
} 
Table 6. Applied pre-sowing strategies (in \% share of regional units) in the reference, glyphosate-freeand herbicide-free-scenarios including soil preservation payments - over all regions

\begin{tabular}{|c|c|c|c|c|c|c|}
\hline \multirow[b]{2}{*}{ Scenario: } & \multicolumn{3}{|c|}{ Plough: 50\% } & \multicolumn{3}{|c|}{ Plough: 0\% } \\
\hline & $\begin{array}{l}\text { Refe- } \\
\text { rence }\end{array}$ & $\begin{array}{c}\text { Glyphosate- } \\
\text { free }\end{array}$ & $\begin{array}{l}\text { Herbicide- } \\
\text { free }\end{array}$ & $\begin{array}{l}\text { Refe- } \\
\text { rence }\end{array}$ & $\begin{array}{c}\text { Glyphosate- } \\
\text { free }\end{array}$ & $\begin{array}{c}\text { Herbicide- } \\
\text { free }\end{array}$ \\
\hline No pre-sowing weed control & $1.7 \%$ & $1.7 \%$ & $1.7 \%$ & $3.4 \%$ & $3.4 \%$ & $3.4 \%$ \\
\hline Cover crop + direct sowing & $0.0 \%$ & $0.0 \%$ & $0.0 \%$ & $0.0 \%$ & $0.0 \%$ & $0.0 \%$ \\
\hline Pure mechanical & $98.2 \%$ & $98.3 \%$ & $98.3 \%$ & $95.5 \%$ & $96.6 \%$ & $96.6 \%$ \\
\hline Partly mechanical & $98.2 \%$ & $98.3 \%$ & $98.3 \%$ & $95.5 \%$ & $96.6 \%$ & $96.6 \%$ \\
\hline No herbicides & $100.0 \%$ & $100.0 \%$ & $100.0 \%$ & $98.9 \%$ & $100.0 \%$ & $100.0 \%$ \\
\hline Herbicide/Glyphosate & $0.0 \%$ & - & - & $1.1 \%$ & - & - \\
\hline
\end{tabular}

Figure 6 and Figure 7 show the potential net profit reductions for the glyphosate-free- and the herbicide-free-scenarios, now accounting for agri-environmental direct payments for soil preservation. Since applying no herbicides is the optimal strategy already in the reference scenario, also the potential losses due to glyphosate-free or herbicide-free cultivation are limited. We find that in the remaining regional units, where glyphosate application is still profitable (only 1.1\%), a ban of only glyphosate already leads farmers to choose herbicide-free production (Table 8). This reflects that the second best strategy is to take soil preservation payments for not applying herbicides. Thus, if glyphosate applications are banned, also the other selective herbicides are not applied anymore and farmers switch to soil preservation payments.

If maize is grown previously, no soil preservation payments are paid and the net profit and yield reductions are similar to those presented in the first results section. Thus, there would be significant economic losses where maize precedes wheat in the crop rotation. The scenario with no-till strategies for the complete field area is unrealistic in this case because the mouldboard plough is important to control for the potential Fusarium infestations from maize. Also the environmental consequences of glyphosate-free and herbicide-free wheat cultivation are similar to those described in section 5.1. 


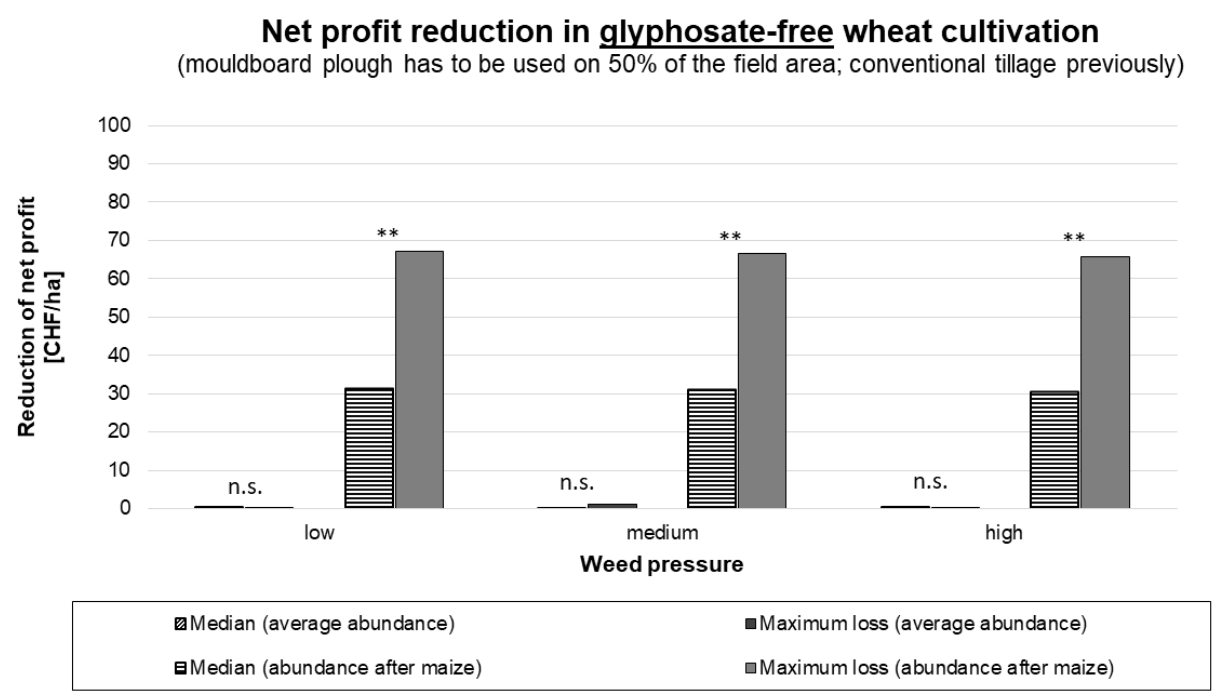

Figure 6. Net profit reductions in glyphosate-free wheat cultivation (scenario with min. $50 \%$ ploughing and soil preservation payments).

Wilcoxon-Mann-Whitney-test is used to test for significant changes. ', *,**, *** and n.s. indicate the significance levels $10 \%, 5 \%, 1 \%, 0.1 \%$ and not significant. In the scenario with average abundance no reduction was observed.

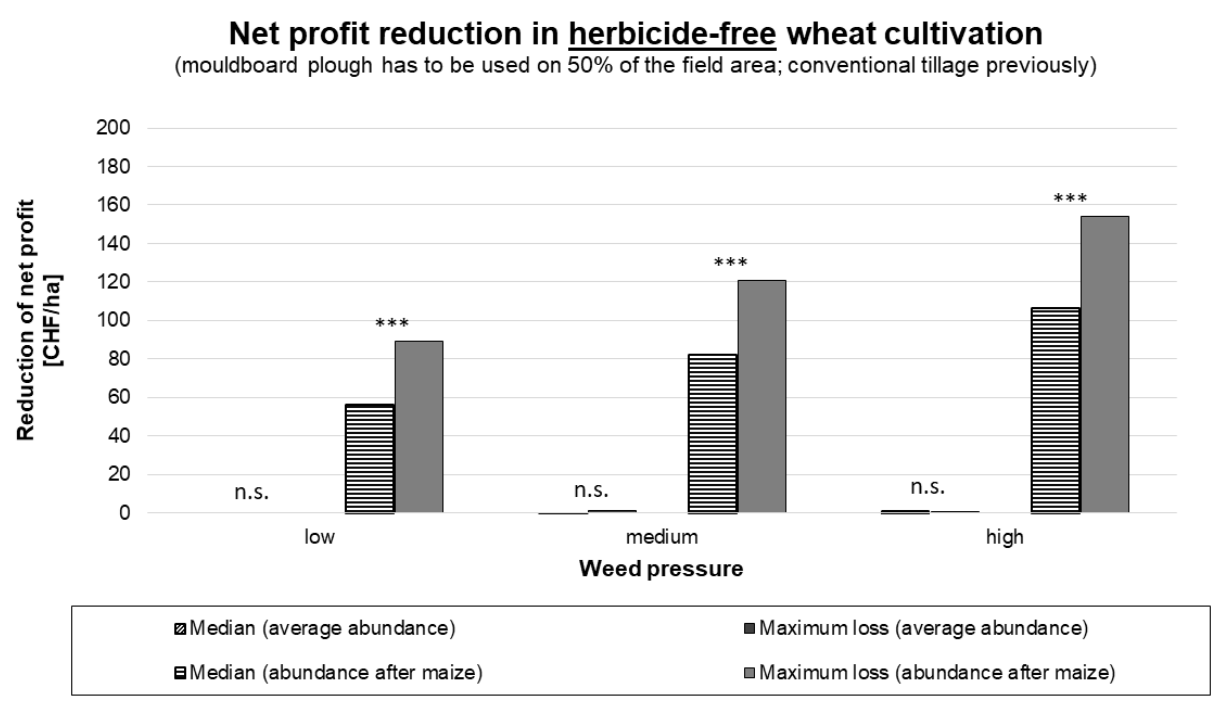

Figure 7. Net profit reductions in herbicide-free wheat cultivation (scenario with min. $50 \%$ ploughing and soil preservation payments).

Wilcoxon-Mann-Whitney-test is used to test for significant changes. ', *,**, *** and n.s. indicate the significance levels $10 \%, 5 \%, 1 \%, 0.1 \%$ and not significant. In the scenario with average abundance no reduction was observed.

\section{Discussion}

In this article, we investigate implications of a) glyphosate-free and b) herbicide-free cultivation of Extenso winter wheat in Switzerland. Our analysis provides a quantification of possible trade-offs on 
economic and environmental dimensions in such scenarios. Interest in these scenarios arises from potential, stricter policies regarding glyphosate and herbicides in the future from agricultural policy but also from consumers and food industry. Under current agricultural policies in Switzerland (in place in 2018), farmers can already get a compensation for production systems with no herbicide applications in combination with soil preservation (reduced tillage strategies) ${ }^{11}$. However, only few farmers take part in this program, although our analysis suggests that these production systems would be the most profitable according to our analysis.

We first analyse farmers' decisions under the assumption that no incentives in the form of agrienvironmental direct payments for soil conservation and herbicide free production exist (section 5.1). This part of the analysis generally also reflects the case where maize is grown before wheat, as farmers are not eligible for soil conservation payments in this situation in order to avoid problems of Fusarium and associated deoxynivalenol (DON) contents. Our analysis shows that in such situations farmers face economic losses when changing to glyphosate-free or herbicide-free wheat cultivation, while concerning the environmental consequences we find reductions in pesticide load. More specifically, in the glyphosate-free-scenario, we find a maximum reduction of the net profit of up to CHF 119/ha. In the herbicide-free-scenario, losses are up to CHF 192/ha.

However, if accounting for currently available agri-environmental payment schemes and assuming crops other than maize are grown previous to wheat, those financial losses are already more than compensated given the current amount of soil preservation payments combined with herbicide-free production payments (section 5.2). The question arises, why farmers do not take part in these "herbicidefree production" programmes, although it would be profitable.

A first explanation is that maize grown before wheat is indeed an important part of the crop sequence of several farms in Switzerland. Furthermore, we do not account for the fact that not using herbicides could increase risks of yield losses (due to quantity but also quality reductions of yields), which could have a strong influence on decision making especially of risk averse farmers. However, we did not find reliable data on current occurrence of such yield losses (we expect them to be close to zero currently) or changes therein. Generally, the yield levels in the Extenso programme lie in the range of organic farming (cf. Honegger et al., 2014). Another reason could be that farmers fear higher weed infestation on

\footnotetext{
${ }^{11}$ Note that after the submission of this paper, a new policy has been launched in 2019. Herbicide-free production is now compensated with CHF 250/ha even without restrictions on tillage activities (Bundesrat, 2019). The policy will be effective starting from autumn 2019, when first wheat seeding takes place. The measure is supposedly a result of too small participation in herbicide-free production under the here investigated policy schemes and increasing policy pressure regarding pesticide use (see also Huber and Finger, 2019, Finger, 2018). Given the foreseeable trade-offs between tillage and herbicide use and given the result of this and other papers, this is an undesirable policy outcome.
} 
subsequent crops if they do not control weeds adequately in wheat production, especially for high-value crops like tubers. Note that our analysis (and the herein reflected discussions in policy and downstream industries) has focused solely on wheat and did not account for the entire crop sequence. Including crop sequences would require detailed weed growth models for the whole crop sequence, which is out of the scope of this article but shall be addressed in future research.

Another important reason for the low participation in these programs could be that farmers currently do not own the necessary equipment to substitute herbicide use. This applies for both, the adoption of reduced tillage practices and equipment for weed control, without spraying herbicides (e.g. comb harrows) ${ }^{12}$. Low adoption might be due to low profitability of such equipment, especially if herbicides are representing the by far cheaper strategy currently. Furthermore, production and market risks play an important role for the non-adoption of new technologies (e.g. Sunding and Zilberman, 2001; Tozer, 2009). In our example, these production and market risks are amplified by technology risks. Newly purchased machinery can be outdated in a few years, given the currently rapid development of agricultural machinery. Furthermore, large policy risks exist in the Swiss case in the form of a direct payment scheme that is bound to a certain time horizon. The Extenso programme was already established in 1992 (El Benni and Lehmann, 2010). The current payment scheme for soil preservation is, however, only scheduled for the period from 2014 to 2019 (see footnote above for currently added policies). Investments in machinery are in contrast usually planned over a longer time span. The standard machine life of a comb harrow is, for example, around 15 years (Gazzarin, 2017). A reduction of policy risks could lead to a higher share of farmers participating in soil preservation schemes, and consequently not applying herbicides in winter wheat. ${ }^{13}$

Solutions to increase adoption rates of the existing soil preservation schemes and to reach a larger share of glyphosate- or even herbicide-free wheat production are manifold. First, the adoption of new technologies could be strengthened. Thus, instead of paying even higher per hectare compensations for herbicide-free production, it would also be an option to support investments in mechanical weed control equipment. Similar investment support schemes already exist as a policy instrument in Switzerland. Yet,

\footnotetext{
${ }^{12}$ Indeed, in the cropping season 2018-2019 about 1000 ha of Extenso wheat are already produced herbicide-free as it was modeled here. This initiative is led by IP Suisse. The harvest is marketed as 'pesticide free' bread (by the baking company 'Fredy's AG').

${ }^{13}$ We also assessed potential losses if farmers do not own alternative weed control equipment such as comb harrows. In order to do so, we excluded all strategies with comb harrows from the strategy matrix. However, also in this scenario, we find that the payments for soil preservation would still be high enough to compensate the losses. We conclude that no chemical weed control would be the optimal strategy under current conditions - even if not all mechanical weed control equipment is available. Only if the payments for soil preservation were abolished, the losses would increase strongly up to a maximum net profit reduction of about CHF 360/ha (online Appendix B, Table A3). In this case also higher yield reductions would occur with a median of 1.5 to $4.9 \mathrm{dt} / \mathrm{ha}$.
} 
Swiss agriculture is dominated by small farm structures and, thus, these incentive schemes should be targeted towards joint investment of several farmers. Furthermore, it is decisive to consider the role of contractors for the establishment of new technologies in such settings (similar to findings for precision farming applications, e.g. Kutter et al., 2011). Beyond governmental actions, there is also a large private sector demand for reduced/ pesticide-free products. Thus, new marketing possibilities (see e.g. 'zéro résidu de pesticides' in France or the here addressed IP Suisse program in Switzerland) may also create additional income opportunities for farmers and allow them to exploit consumers' willingness to pay for "reduced pesticide use" products (Bernard and Bernard, 2010; Bazoche et al., 2013). Current policy and industry discussions show that this strategy is also of importance beyond our Swiss case study.

The potential relevance of policy risks for non-adoption of mechanical strategies implies that policy programs should be long-term oriented. For example, herbicide-free production could be integrated into the existing regulations of the Extenso program - or an 'Extenso Plus' programme might be created. This also contributes to a simplification of existing payment schemes. ${ }^{14}$ Furthermore, a step-wise implementation from glyphosate- to herbicide-free production could facilitate the adoption of herbicide substitutes by farmers.

Beyond our case study, the implementation of policy programmes based on agri-environmental payments to support substitution of pesticide use in production seems an appropriate component of a coherent policy framework (Finger, 2018). In such a framework, the taxation of pesticides could play a role: by internalising negative external effects of herbicide (or in general pesticide) use, incentives are given to substitute with mechanical strategies. Furthermore, tax revenues could flow back into the agricultural sector to subsidise new technologies, creating a leverage effect of such taxation schemes (Finger et al., 2017).

Our results show that negative environmental side-effects due to a ban of glyphosate or herbicides could be limited in Swiss Extenso wheat production. More specifically, because glyphosate-free or herbicide-free production would be combined with uptake of reduced tillage activities in our case study, there is a smaller increase in soil erosion or energy usage compared to a change to complete mouldboard ploughing. However, such negative side-effects possibly arise in situations that require tillage to control for Fusarium and associated deoxynivalenol (DON) contents, for example if maize is grown before wheat. In addition, current policy developments (see footnote above), granting agri-environmental direct payments for herbicide-free production without restrictions on tillage will imply stronger negative sideeffects also for Switzerland. Future policies need to better integrate conflicting policy goals such as the

\footnotetext{
${ }^{14}$ This is further required in Switzerland as some of the Swiss cantons even have extra payments schemes for specific production systems (e.g. payments for not using glyphosate, not using herbicides or payments for undersown crops). Fathoming this jungle of direct payments is not an easy task und unifying some schemes may increase acceptance rates.
} 
reduction of soil erosion and pesticide load reduction. Efficient policies might require spatially targeted measures, e.g. accounting for spatial heterogeneity in soil erosion risk.

The here modelled herbicide-free Extenso wheat production is almost pesticide free, except for seed treatments. For marketing purposes of downstream sectors and human health and environmental risk exposure, it could be attractive to cultivate wheat also without such seed treatment, i.e. 'pesticide-free' (but yet not organic). However, the consequences are not easy to evaluate since different diseases can be controlled with seed treatment and information on yield reductions by different seed- and soil-borne diseases were not available.

There are various directions in which to extend our analysis. Some were already mentioned, e.g. the extension of the analysis to entire crop sequences. This also addresses that glyphosate application is in our model only done pre-sowing, while the application of glyphosate after cereal harvest is also relevant and a cheap option to control for grass weeds and volunteer seeds in the crop sequence. This option would still exist even if herbicides are excluded from wheat cultivation because the production period ends with the harvest. If the following crop shall also be grown under herbicide-free Extenso conditions, this option would have to be substituted by tillage strategies, late sowing dates and choosing more competitive varieties and therefore require an additional analysis.

In a next step, the bio-economic model presented in this article can also be used to analyse the economic performance of smart farming techniques which might also include weeding robots that could contribute to further increase profits of extensively grown cereals (Walter et al., 2017; Finger et al., 2019), e.g. deriving the efficacy and costs parameters needed for smart farming techniques to become a viable alternative.

\section{Conclusions}

We develop a bio-economic model for weed control decisions in the cultivation of Extenso winter wheat production in Switzerland. Currently, 50\% of wheat is cultivated under the Extenso programme in Switzerland, which already prohibits the use of insecticides, fungicides and growth regulators. This model is used to simulate the effects of glyphosate-free and herbicide-free wheat cultivation ex-ante. The exclusion of glyphosate or all herbicides from the Extenso wheat production reflects current discussions in Swiss wheat value chains. Our analysis quantifies the potential implications of such bans for weed control strategies, yields, profits and environmental impacts.

Our results show that herbicide-free wheat production is indeed possible and can be economically viable. Such a step would imply low to moderate economic losses for farmers in our case study. This is especially due to the fact that agri-environmental direct payments in Switzerland support herbicide-free production strategies. In addition, we also find yield reductions to be moderate, especially because herbicides are substituted with mainly mechanical substitutes for weed control. We find significant 
reductions of risks for the environment and human health due to pesticide use if glyphosate (and all herbicides) are removed. Effects on the energy balance of wheat production are ambiguous.

Yet, efforts especially with respect to technology and management are needed to further combine pesticide risk reduction efforts and the need to maintain or increase crop yields, especially if going from the Swiss to the global scale. Policy steps to foster adoption of herbicide-free production should particularly aim to create stable and coherent policy environments. This is of particular importance, as the reduction of herbicide use can create trade-offs, e.g. between soil erosion and reductions of the risks from herbicide use. Our example shows that this trade-off can be avoided to some extent if incentive schemes towards herbicide use reduction steps are combined with incentive schemes for the adoption of reduced tillage practices. The here developed bio-economic modelling approach is an important advancement to quantify effects of pesticide policies and allows to reveal and to quantify the arising trade-offs. Thus, such modelling approaches should be developed further to allow the assessment of pesticide policies.

\section{References}

Bazoche, P., Combris, P., Giraud-Héraud, E., Seabra Pinto, A., Bunte, F. and Tsakiridou, E. (2013). Willingness to pay for pesticide reduction in the EU: nothing but organic? European Review of Agricultural Economics 41(1): 87-109.

Benbrook, C. M. (2016). Trends in glyphosate herbicide use in the United States and globally. Environmental Sciences Europe 28(1): 3.

Bernard, J. C. and Bernard, D. J. (2010). Comparing parts with the whole: willingness to pay for pesticide-free, non-GM, and organic potatoes and sweet corn. Journal of Agricultural and Resource Economics, 457-475.

BLW - Bundesamt für Landwirtschaft (2016). Agrarbericht 2016. Bundesamt für Landwirtschaft, Bern.

Boessinger, M., Dietiker, D., Droz, P., Dugon, J., Graf, S., Hanhart, J. et al. (2015). Deckungsbeiträge - Ausgabe 2015 - Getreide, Hackfrüchte, Übrige Ackerkulturen, Futterbau, Spezialkulturen, Tierhaltung. AGRIDEA, Lindau and Lausanne.

Böcker, T. and Finger, R. (2017). A Meta-Analysis on the Elasticity of Demand for Pesticides. Journal of Agricultural Economics 68(2): 518-533.

Böcker, T. and Finger, R. (2018a). Implikationen eines herbizidlosen Extenso-Weizenanbaus in der Schweiz. Agrarforschung Schweiz 9(9): 296-305. 
Böcker, T. and Finger, R. (2018b). Bio-economic model on weed control in cultivation of wheat. ETH Zürich, Zürich. Online: https://doi.org/10.3929/ethz-b-000278419 [02 March 2019].

Böcker, T., Britz, W. and Finger, R. (2018). Modelling the Effects of a Glyphosate Ban on Weed Management in Silage Maize Production. Ecological Economics 145: 182-193.

Böcker, T., Britz, W., Möhring, N. and Finger, R. (2019). Böcker, T., Britz, W., Möhring, N. and Finger, R. (2019). An economic and environmental assessment of a glyphosate ban for the example of maize production. European Review of Agricultural Economics. In Press. https://doi.org/10.1093/erae/jby050

Bosnic, A. C. and Swanton, C. J. (1997a). Economic decision rules for postemergence herbicide control of barnyardgrass (Echinochloa crus-galli) in corn (Zea mays). Weed Science 45: 557-563.

Bosnic, A. C. and Swanton, C. J. (1997b). Influence of barnyardgrass (Echinochloa crus-galli) time of emergence and density on corn (Zea mays). Weed Science 45: 276-282.

Brower, L. P., Taylor, O. R., Williams, E. H., Slayback, D. A., Zubieta, R. R. and Ramírez, I. (2012). Decline of monarch butterflies overwintering in Mexico: is the migratory phenomenon at risk? Insect Conservation and Diversity 5: 95-100.

Brust, J., Gerhards, R., Karanisa, T., Ruff, L. and Kipp., A. (2011). Why Undersown and Cover Crops Become Important Again for Weed Suppression in European Cropping Systems. Gesunde Pflanzen 63: 191-198.

Bundesrat (2017). Aktionsplan zur Risikoreduktion und nachhaltigen Anwendung von Pflanzenschutzmitteln. September 2017, 78p., Download (in German) https://www.newsd.admin.ch/newsd/message/attachments/49600.pdf

Bundesrat (2019). Verordnung über die Direktzahlungen an die Landwirtschaft. https://www.admin.ch/opc/de/classified-compilation/20130216/index.html

Christensen, T., Pedersen, A. B., Nielsen, H. O., Mørkbak, M. R., Hasler, B. and Denver, S. (2011). Determinants of farmers' willingness to participate in subsidy schemes for pesticide-free buffer zones - A choice experiment study. Ecological Economics 70(8): 1558-1564.

Cousens, R. (1985). A simple model relating yield loss to weed density. Annals of Applied Biology 107: 239-252.

Damalas, C. A. (2009). Understanding benefits and risks of pesticide use. Scientific Research and Essays, 4(10), 945-949. 
Danne, M., Mußhoff, O. and Schulte, M. (2018). Analysing the importance of glyphosate as part of agricultural srategies: A discrete choice experiment (No. 1802). Diskussionspapiere, Department für Agrarökonomie und Rurale Entwicklung.

Doppler, T., Mangold, S., Wittmer, I., Spycher, S., Comte, R., Stamm, C., Singer, H., Junghans, M. and Kunz, M. (2017). Hohe PSM-Belastung in Schweizer Bächen. NAWA-SPEZ-Kampagne untersucht Bäche in Gebieten intensiver landwirtschaftlicher Nutzung. Aqua \& Gas 97 (4): 46-56.

El Benni, N. and Lehmann, B., 2010. Swiss agricultural policy reform: landscape changes in consequence of national agricultural policy and international competition pressure. In: Primdahl, J., Swaffield, S. (eds): Globalisation and Agricultural Landscapes - Change Patterns and Policy trends in Developed Countries. Cambridge University Press, Cambridge, pp. 73-94.

Eurostat (2018). Bilateral exchange rates. Online: http://ec.europa.eu/eurostat/data/database [09 January 2018].

Federal Office for Agriculture (ed.) (2009). Bodeneignungskarte der Schweiz - Datenbeschreibung. Bundesamt für Landwirtschaft BLW - Fachbereich Agrarinformationssystem, Bern.

Fenaco (ed.) (2018). Zielsortiment - Pflanzenbehandlungsmittel im Acker und Futterbau. Fenaco Genossenschaft, Bern.

Finger, R. (2014). Risk considerations in the economic assessment of low-input crop production techniques: an example from Swiss wheat production. International Journal of Agricultural Resources, Governance and Ecology 10 (1): 63-77.

Finger, R. (2018). Take a holistic view when making pesticide policies stricter. Nature 556, 174

Finger, R. and El Benni, N. (2013). Farmers' adoption of extensive wheat production - Determinants and implications. Land Use Policy 30: 206-213.

Finger, R., Möhring, N., Dalhaus, T., Böcker, T. (2017). Revisiting pesticide taxation schemes. Ecological Economics 134: 263-266

Finger, R., Swinton, S., El Benni, N. and Walter, A. (2019). Precision Farming at the Nexus of Agricultural Production and the Environment. Annual Review of Resource Economics. In Press.

Gardebroek, C. (2006). Comparing risk attitudes of organic and non-organic farmers with a Baysian random coefficient model. European Review of Agricultural Economics 33 (4): 485-510.

Gazzarin, C. (2017). Maschinenkosten 2017. Agroscope Transfer Nr. 190/2017. 
Gehring, K. (2003). Unkrautbekämpfung im Getreidebau. Bayerische Landesanstalt für Landwirtschaft, Freising-Weihenstephan.

Hall, D. C., and Norgaard, R. B. (1973). On the timing and application of pesticides. American Journal of Agricultural Economics, 55(2), 198-201.

Hanke, I., Wittmer, I., Bischofberger, S., Stamm, C. and Singer, H. (2010). Relevance of urban glyphosate use for surface water quality. Chemosphere 81: 422-429.

Hardaker, J. B., Huirne, R. B. M., Anderson, J. R. and Lien, G. (2004). Coping with Risk in Agriculture. $2^{\text {nd }}$ ed., CABI Publishing, Wallingford, UK.

Hatcher, P. E. and Melander, B. (2003). Combining physical, cultural and biological methods: prospects for integrated non-chemical weed management strategies. Weed Research 43 (5): 303-322.

Helander, M., Saloniemi, I. and Saikkonen, K. (2012). Glyphosate in northern ecosystems. Trends in Plant Science 17 (10): 569-574.

Honegger, A., Wittwer, R., Hegglin, D., Oberholzer, H.-R., de Ferron, A., Jeanneret, P. and van der Heijden, M. (2014). Auswirkungen langjähriger biologischer Landwirtschaft. Agrarforschung Schweiz 5 (2): 44-51.

Huber, R., Snell, R., Monin, F., Brunner, S., Schmatz, D. and Finger R. (2017). Interaction effects of targeted agri-environmental payments on non-marketed goods and services under climate change in a mountain region. Land Use Policy 66: 49-60.

Huber, R., Finger, R. (2019). Popular initiatives increasingly stimulate agricultural policy in Switzerland. EuroChoices. In Press DOI: 10.1111/1746-692X.12209

Hülsbergen, K.-J., Feil, B., Biermann, S., Ranthke, G.-W., Kalk, W. D. and Diepenbrock, W. (2001). A method of energy balancing in crop production and its application in a long-term fertilizer trial. Agriculture, Ecosystems and Environment 86 (3): 303-321.

Huntscha, S., Stravs, M. A., Bühlmann, A., Ahrens, C. H., Frey, J. E., Pomati, F., Hollender, J., Buerge, I. J., Balmer, M. E. and Poiger, T. (2018). Seasonal Dynamics of Glyphosate and AMPA in Lake Greifensee: Rapid Microbial Degradation in the Epilimnion During Summer. Environmental Science \& Technology 52 (8): 4641-4649.

Info Flora (2018). Verbreitungskarten Schweiz. Chambésy-Genève, Switzerland.IP-Suisse (2016). Richtlinien für Getreide, as of 27 June 2016. IP-Suisse, Zollikofen. 
IP-Suisse (2017). IP-Suisse Weizenanbau für die Ernte 2018. Online: https://www.ipsuisse.ch/CMS/ModanFileHandler.axd?DateiGUID=e7b3fa06-cb99-40c9-856deda6040fdd9a [09 January 2018].

Kirchmeier, H. and Demmel, M. (2007). Wirkung von Maisstrohzerkleinerung und Bodenbearbeitung auf Fusariuminfektionen des Winterweizens nach Körnermais. Bayerische Landesanstalt für Landwirtschaft: Freising-Weihenstephan.

Kudsk, P., Jørgensen, L. N. and Ørum, J. E. (2018). Pesticide Load - A new Danish pesticide rik indicator with multiple applications. Land Use Policy 70: 384-393.

Kutter, T., Tiemann, S., Siebert, R., \& Fountas, S. (2011). The role of communication and co-operation in the adoption of precision farming. Precision Agriculture 12(1): 2-17.

Lichtenberg, E., and Zilberman, D. (1986). The econometrics of damage control: why specification matters. American Journal of Agricultural Economics 68(2): 261-273.

Melander, B., Rasmussen, I. A. and Bàrberi, P. (2005). Integrating physical and cultural methods of weed control—examples from European research. Weed Science, 53(3), 369-381.

Meraner, M, Finger, R. (2018). Risk perceptions, preferences and management strategies: Evidence from a case study using German livestock farmers. Journal of Risk Research. In Press

Möhring, N., Gaba, S. and Finger, R. (2019). Quantity based indicators fail to identify extreme pesticide risks. Science of the Total Environment 646: 503-523

Munz, N., Leu, C. \& Wittmer, I. (2012). Pestizidmessungen in Fliessgewässern - Schweiz-weite Auswertung. Aqua \& Gas 11, 32-41.

Nail, E. L., Young, D. L., \& Schillinger, W. F. (2007). Diesel and glyphosate price changes benefit the economics of conservation tillage versus traditional tillage. Soil and Tillage Research, 94(2), 321327.

O’Donovan, J. T., de St. Remy, E. A., O’Sullivan, P. A., Dew, D. A. and Sharma, A. K. (1985). Influence of the Relative Time of Emergence of Wild Oat (Avena fatua) on Yield Loss of Barley (Hordeum vulgare) and Wheat (Triticum aestivum). Weed Science 33: 498-503

Oerke, E.-C. (1994). Estimated crop losses due to pathogens, animal pests and weeds. In: Oerke, E.-C., Dehne, H.-W., Schönbeck, F. and Weber, A. (eds). Crop production and crop protection Estimated losses in major food and cash crops. Elsevier: Amsterdam. 
Pimentel, D., McLaughlin, L., Zepp, A., Lakitan, B., Kraus, T., Kleinman, P., Vancini, F., Roach, W. J., Graap, E., Keeton, W. S. and Selig, G. (1993). Environmental and economic effects of reducing pesticide use in agriculture. Agriculture and the Environment 46: 273-288.

Poiger, T., Buerge, I. J., Bächli, A., Müller, M. D. and Balmer, M. E. (2017). Occurrence of the herbicide glyphosate and its metabolite AMPA in surface waters in Switzerland determined with on-line solid phase extraction LC-MS/MS. Environmental Science and Pollution Research 24 (2): 1588-1596.

Schmitz, P. M. and Garvert, H. (2012). Agro-economic analysis of the use of glyphosate in Germany. Journal für Kulturpflanzen 64: 150-162.

Schulte, M. C., Theuvsen, L., Wiese, A. and Steinmann, H.-H. (2017). Die ökonomische Bewertung von Glyphosat im deutschen Ackerbau. In: Schriften der Gesellschaft für Wirtschafts- und Sozialwissenschaften des Landbaus e.V. (ed.), Agrar- und Ernährungswirtschaft: Regional vernetzt und global erfolgreich. Landwirtschaftsverlag, Münster, 29-41

Spycher, S., Badertscher, R. and Daniel, O. (2013). Indikatoren für den Einsatz von Pflanzenschutzmitteln in der Schweiz. Agrarforschung Schweiz 4(4): 192-199.

Spycher, S., Mangold, S., Doppler, T., Junghans, M., Wittmer, I., Stamm, C. and Singer, H. (2018) Pesticide risks in small streams - how to get as close as possible to the stress imposed on aquatic organisms. Environmental Science and Technology 52 (8): 4526-4535

Streit, B., Rieger, S. B., Stamp, P. and Richner, W. (2003). Weed populations in winter wheat as affected by crop sequence, intensity of tillage and time of herbicide application in a cool and humid climate. Weed Research 43: 20-32.

Sunding, D. and Zilberman, D. (2001). The agricultural innovation process: research and technology adoption in a changing agricultural sector. Handbook of Agricultural Economics 1, 207-261.

Swinton, S. M. and Van Deynze, B. (2017). Hoes to herbicides: economics of evolving weed management in the United States. The European Journal of Development Research 29(3): 560-574.

Swiss Granum (n.d.). Marktzahlen - Preise - Richtpreise Brotgetreide. Online: http://www.swissgranum.ch/preise [16 May 2018].

Tarazona, J. V., Court-Marques, D., Tiramani, M., Reich, H., Pfeil, R., Istace, F. and Crivellente, F. (2017). Glyphosate toxicity and carcinogenicity: a review of the scientific basis of the European Union assessment and its differences with IARC. Archives of Toxicology 91 (8): 2723-2743.

Tembo, G., Brorsen, B. W., Epplin, F. M., and Tostão, E. (2008). Crop input response functions with stochastic plateaus. American Journal of Agricultural Economics 90(2): 424-434. 
Tozer, P. R. (2009). Uncertainty and investment in precision agriculture-Is it worth the money? Agricultural Systems 100(1-3): 80-87.

Walter, A., Finger, R., Huber, R. and Buchmann, N. (2017). Smart farming is key to developing sustainable agriculture. PNAS 114 (24): 6148-6150.

Wilson, R. S., Hooker, N., Tucker, M., LeJeune, J. and Doohan, D. (2009). Targeting the farmer decision making process: a pathway to increased adoption of integrated weed management. Crop Protection 28 (9): $756-764$.

Wittwer, R., Dorn, B., Jossi, W., Zihlmann, U. and van der Heijden, M. (2013). Zwischenfrüchte als wichtiges Puzzleteil für den pfluglosen ökologischen Landbau. In: Neuhoff, D., Stumm, C., Ziegler, S., Rahmann, G., Hamm, U and Köpke, U. (eds): Ideal und Wirklichkeit - Perspektiven Ökologischer Landbewirtschaftung. Verlag Dr. Köster: Berlin.

Wittmer, I., Moschet, C., Simovic, J., Singer, H., Stamm, C., Hollender, J., Junghans, M. \& Leu, C. (2014). Über 100 Pestizide in Fliessgewässern - Programm Nawa Spez zeigt die hohe Pestizidbelastung der Schweizer Fliessgewässer auf. Aqua \& Gas 3, 32-43.

Zimdahl, R. L. (2013). Fundamentals of Weed Science. $4^{\text {th }}$ edition, Elsevier: Amsterdam.

Zorn, A., Musa, T. and Lips, M. (2018). Was kostet die Vermeidung des Pilzgifts Deoxynivalenol im Weizenanbau? Agrarforschung Schweiz 9 (2): 63-65. 


\section{Online Appendix B}

\section{Agricultural land use potential in Switzerland}

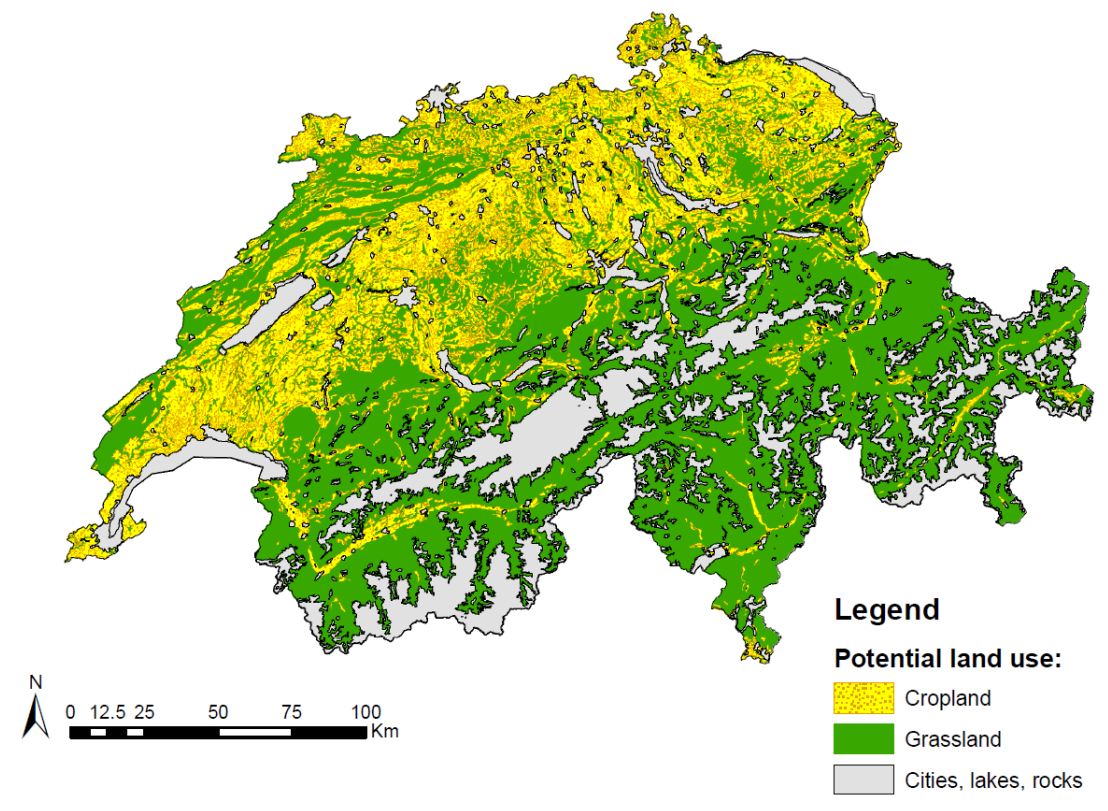

Figure A1. Potential land use in Switzerland.

Data reference: Federal Office for Agriculture (2009).

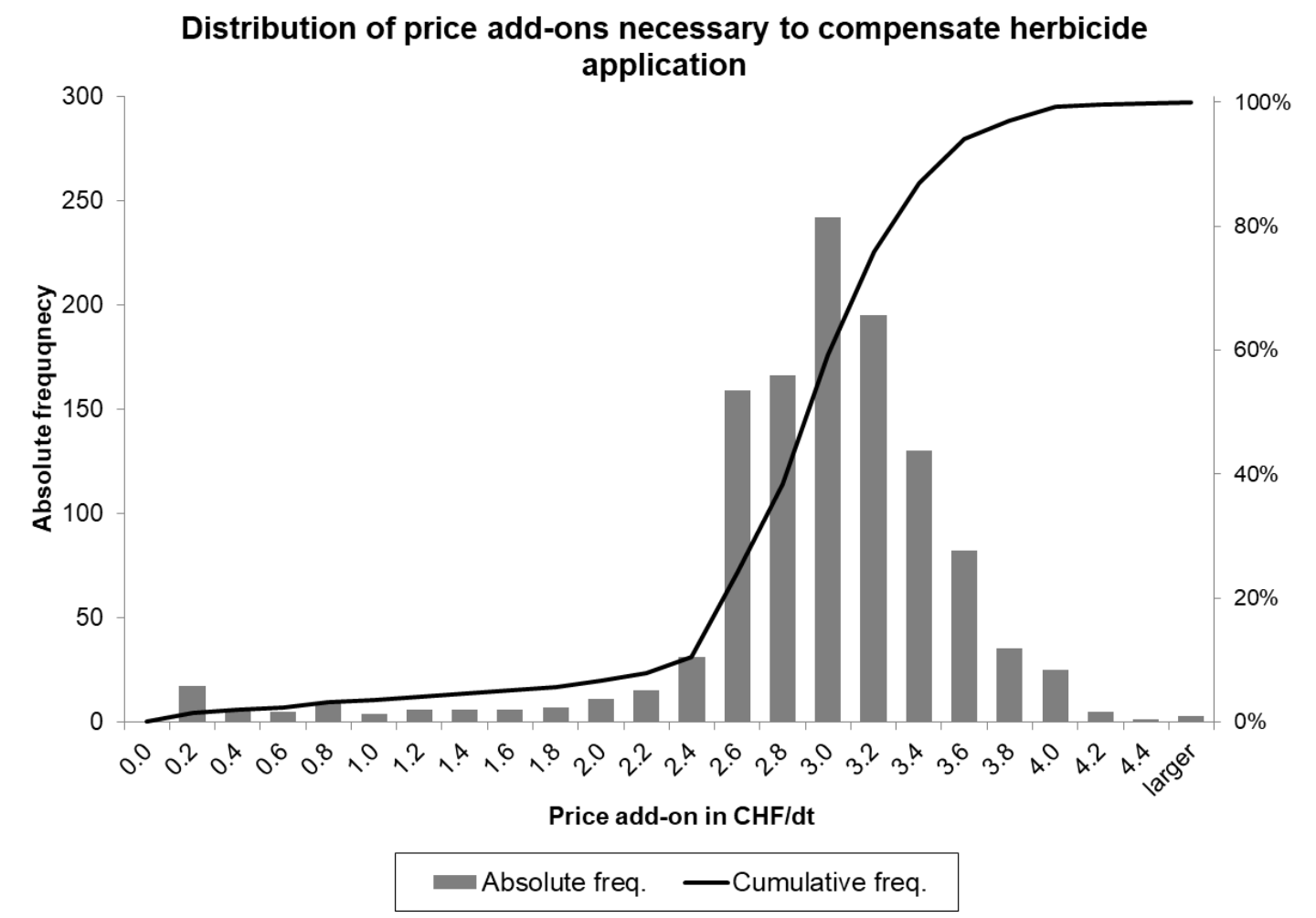

Figure A2. Histogram of necessary price mark-ups to compensate financial losses (scenario with high weed pressure, average abundance and conventional tillage before). 



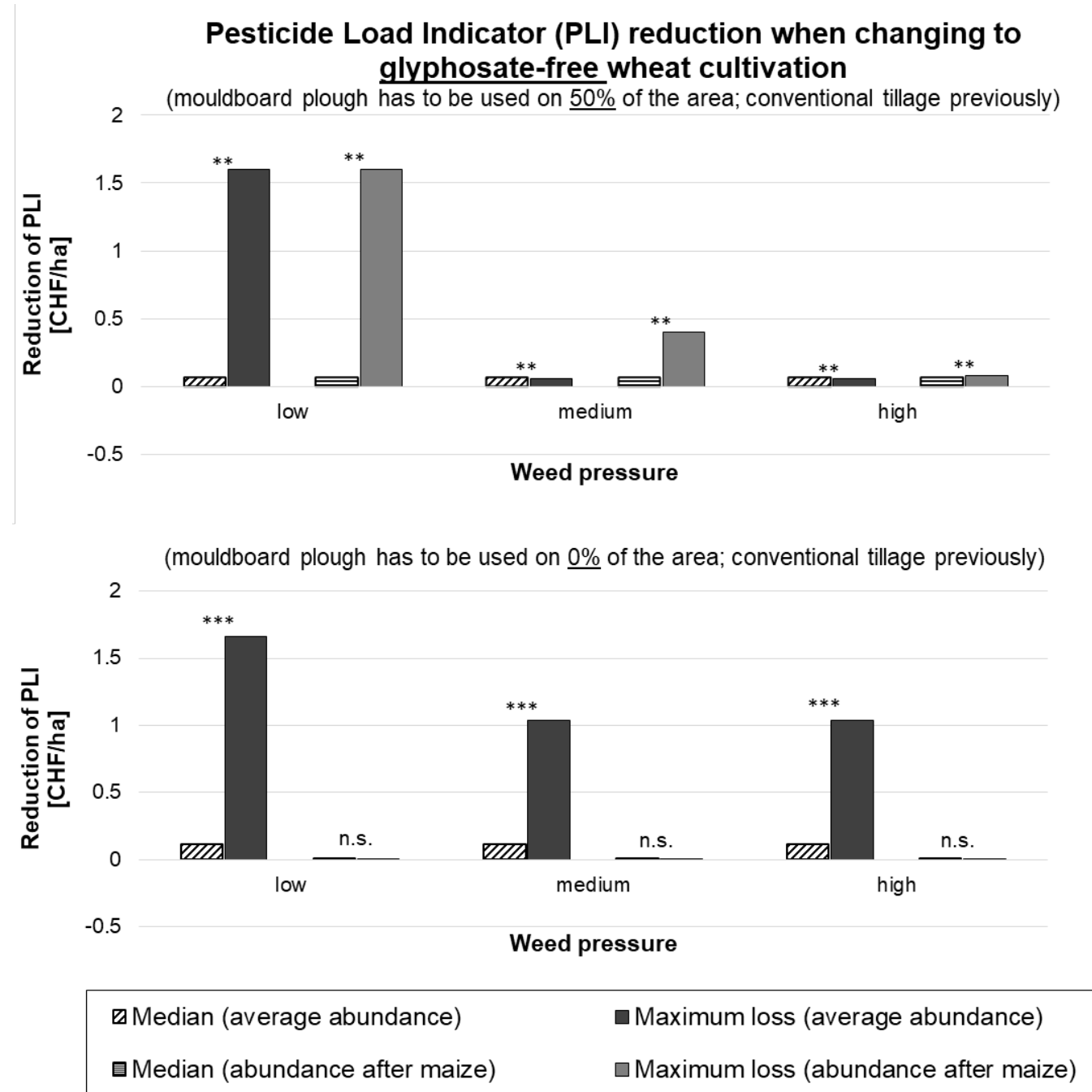

Figure A3. Median and maximum reduction of the Pesticide Load Indicator for the scenarios with min. $50 \%$ ploughing and with no compulsory ploughing.

Wilcoxon-Mann-Whitney-test is used to test for significant changes. ', ${ }^{*}, * *, * * *$ and n.s. indicate the significance levels $10 \%, 5 \%, 1 \%, 0.1 \%$ and not significant. 
Histogram of the change in energy consumption in herbicide-free wheat cultivation



Figure A4. Histogram of the change of direct and indirect energy consumption when changing to herbicide-free wheat cultivation (scenario with compulsory 50\% mouldboard plough on the area) Negative values show less energy consumption, positive values show increased energy consumption due to a change to herbicide-free wheat cultivation. 
Table A1. Description of data sources

\begin{tabular}{|c|c|c|c|c|}
\hline Data & Description & Data Source & Publically available? & Further descriptions \\
\hline $\begin{array}{l}\text { Regional } \\
\text { abundance } \\
\text { of weeds in } \\
\text { Switzerland }\end{array}$ & $\begin{array}{l}\text { Historical observations } \\
\text { on regional abundance } \\
\text { of weeds ( } 1 \mathrm{~km} \times 1 \mathrm{~km} \\
\text { raster) }\end{array}$ & Info Flora (2018) & $\begin{array}{l}\text { Yes, can be downloaded at } \\
\text { https://www.infoflora.ch/de/ }\end{array}$ & $\begin{array}{l}\text { See } \\
\text { https://www.infoflora.ch/de/ }\end{array}$ \\
\hline $\begin{array}{l}\text { Field } \\
\text { calendar } \\
\text { data }\end{array}$ & $\begin{array}{l}\text { Detailed, historical } \\
\text { records of field } \\
\text { management } \\
\text { strategies (108 Swiss } \\
\text { winter wheat farmers } \\
\text { from 2009-2013). }\end{array}$ & $\begin{array}{l}\text { Central Evaluation of } \\
\text { Agri-environmental } \\
\text { Indicators (Agroscope, } \\
\text { Switzerland) }\end{array}$ & $\begin{array}{l}\text { No, data are provided under confidentiality agreements. } \\
\text { Data access can be applied for at } \\
\text { https://www.agroscope.admin.ch/agroscope/en/home/t } \\
\text { opics/environment-resources/monitoring- } \\
\text { analytics/research-projects/swiss-agri-environmental- } \\
\text { data-network.html }\end{array}$ & $\begin{array}{l}\text { See Spycher et al. (2013) and } \\
\text { Möhring et al. (2019). }\end{array}$ \\
\hline $\begin{array}{l}\text { Attainable } \\
\text { Yield }\end{array}$ & $\begin{array}{l}\text { Approximated through } \\
\text { yearly, regional } \\
\text { quantities delivered by } \\
\text { producers to IP-Suisse. }\end{array}$ & $\begin{array}{l}\text { IP-Suisse } \\
\text { (https://www.ipsuisse. } \\
\text { ch/) }\end{array}$ & $\begin{array}{l}\text { No, the data was provided under confidentiality } \\
\text { agreements. Contact partner was IP-Suisse } \\
\text { (https://www.ipsuisse.ch/). }\end{array}$ & $\begin{array}{l}\text { See } \\
\text { https://www.ipsuisse.ch/. }\end{array}$ \\
\hline $\begin{array}{l}\text { Cost } \\
\text { parameters }\end{array}$ & $\begin{array}{l}\text { Cost parameters for } \\
\text { management activities }\end{array}$ & $\begin{array}{l}\text { Böcker et al. (2018), } \\
\text { Gazzarin (2017), } \\
\text { Boessinger et al. } \\
\text { (2015). }\end{array}$ & $\begin{array}{l}\text { Yes, see Böcker et al. (2018), Gazzarin (2017), Boessinger } \\
\text { et al. (2015). }\end{array}$ & $\begin{array}{l}\text { See Böcker et al. (2018), } \\
\text { Gazzarin (2017) and } \\
\text { Boessinger et al. (2015). }\end{array}$ \\
\hline
\end{tabular}


Table A2. Pesticide Load ${ }^{\mathrm{a}}$ for selected herbicide products

\begin{tabular}{llr}
\hline \multicolumn{1}{c}{ Active Ingredient } & Exemplary herbicide product & Load \\
\hline Glyphosate & Touchdown System 4 & 0.426 \\
Diflufenican, Flufenacet & Herold SC & 1.350 \\
Florasulam, Tritosulfuron & Biathlon 4D & 1.542 \\
Pendimethalin & Malibu & 1.707 \\
Pinoxaden & Avero & 0.014 \\
\hline
\end{tabular}

\footnotetext{
a The unit is Load per (maximum) standard treatment. The load values need to be weighted with the application rate and the standard area dose in order to get per hectare values. As Load is calculated per product and not per active ingredient the values are shown based on exemplary products, which are chosen as part of the farmers' preand post-sowing strategies.
} 
Table A3. Potential losses due to glyphosate-free and herbicide-free wheat cultivation without soil preservation payments and no harrows in machinery equipment

\begin{tabular}{|c|c|c|c|c|c|c|}
\hline & & & \multicolumn{2}{|c|}{$\begin{array}{c}\text { Reduction of net profit } \\
{[\mathrm{CHF} / \mathrm{ha}]}\end{array}$} & \multicolumn{2}{|c|}{$\begin{array}{l}\text { Yield reduction } \\
\text { [dt/ha] }\end{array}$} \\
\hline & & & $\begin{array}{l}\text { Glyphosate- } \\
\text { free }\end{array}$ & $\begin{array}{l}\text { Herbicide- } \\
\text { free }\end{array}$ & $\begin{array}{l}\text { Glyphosate- } \\
\text { free }\end{array}$ & $\begin{array}{l}\text { Herbicide- } \\
\text { free }\end{array}$ \\
\hline \multirow{15}{*}{ 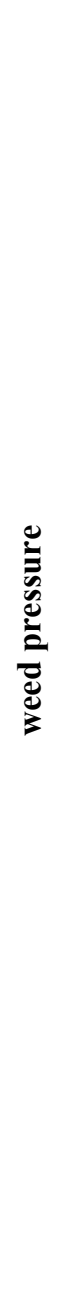 } & \multirow{5}{*}{ low } & Max & -178.7 & -238.9 & -6.2 & -7.3 \\
\hline & & Min & -2.3 & -2.3 & 0.8 & -0.9 \\
\hline & & Median & -117.3 & -182.3 & -1.5 & -3.5 \\
\hline & & $\begin{array}{l}\text { Wilcoxon- } \\
\text { Mann- } \\
\text { Whitney- } \\
\text { test }\end{array}$ & $* * *$ & $* * *$ & $* * *$ & $* * *$ \\
\hline & & St. dev. & 22.1 & 36.1 & 0.9 & 0.9 \\
\hline & \multirow{5}{*}{ medium } & Max & -178.0 & -287.9 & -5.3 & -8.5 \\
\hline & & Min & -2.2 & -4.4 & 0.8 & -1.2 \\
\hline & & Median & -117.1 & -222.9 & -1.5 & -3.5 \\
\hline & & $\begin{array}{l}\text { Wilcoxon- } \\
\text { Mann- } \\
\text { Whitney- } \\
\text { test }\end{array}$ & $* * *$ & $* * *$ & $* * *$ & $* * *$ \\
\hline & & St. dev. & 22.2 & 43.3 & 0.9 & 0.9 \\
\hline & \multirow{5}{*}{ high } & Max & -176.7 & -358.1 & -5.6 & -9.3 \\
\hline & & Min & -1.8 & -1.5 & 0.8 & -1.2 \\
\hline & & $\begin{array}{l}\text { Wilcoxon- } \\
\text { Mann- } \\
\text { Whitney- } \\
\text { test }\end{array}$ & -116.9 & -282.2 & -1.5 & -4.9 \\
\hline & & $\begin{array}{l}\text { Wilcoxon- } \\
\text { Mann- } \\
\text { Whitney- } \\
\text { test }\end{array}$ & $* * *$ & $* * *$ & $* * *$ & $* * *$ \\
\hline & & St. dev. & 22.4 & 60.7 & 0.9 & 0.9 \\
\hline
\end{tabular}

${ }^{a}$ To test if the results are significantly different from zero, a Wilcoxon-Mann-Whitney test is used.

Wilcoxon-Mann-Whitney-test is used to test for significant changes. ', *, **, *** and n.s. indicate the significance levels $10 \%, 5 \%, 1 \%, 0.1 \%$ and not significant. 